\title{
أدب الأوبئة في التراث النقدي والبلاغي - دراسة في شعر علي الدرويش وثقولا الاسطمبولي
}

pidemiological literature in the monetary and rhetorical heritage - A study in poetry Ali Darwish and Nikola El estambuly

\section{slel}

\section{أ.مشار ك.دكة كتور / الهيد محمد ساله}

قسم اللغة العربية - كلية اللغات والاتصال- جامعة السلطان زين العابدين - ماليزيا

Doi: 10.12816/mdad.2020.122950

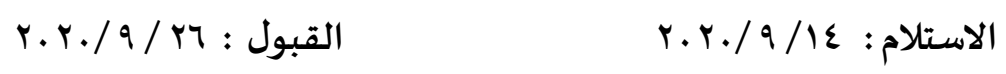

جرت العادة أن يتعايش الأدب مع الأحداث الجارية التي يمر بها العالم تأثثيرا

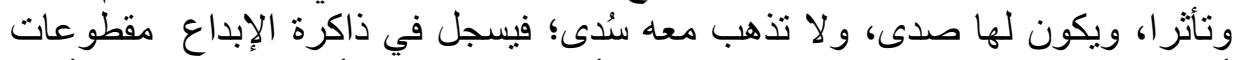

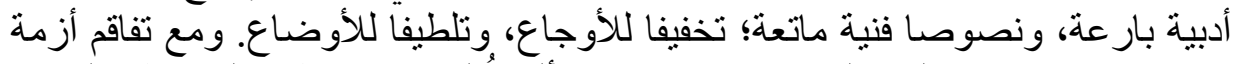

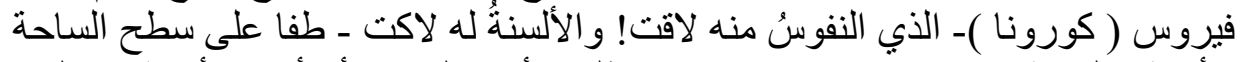

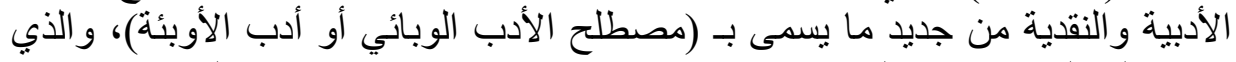

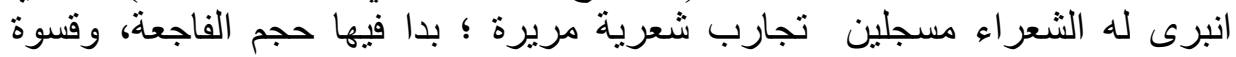

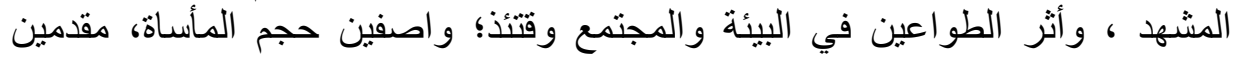

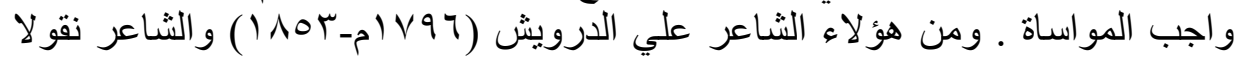

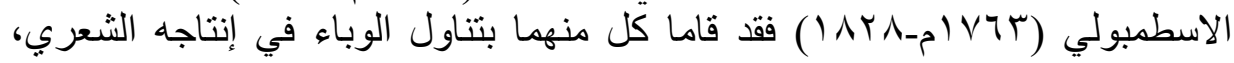

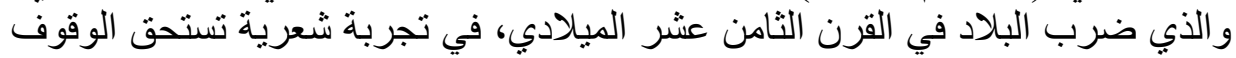

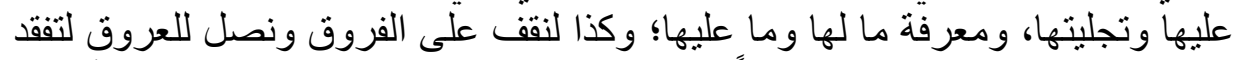

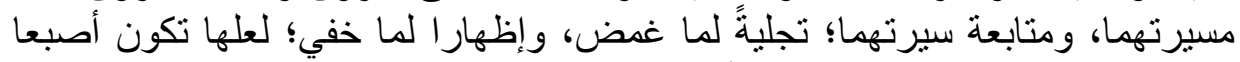

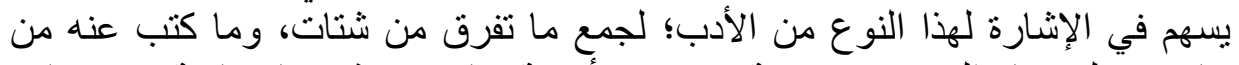

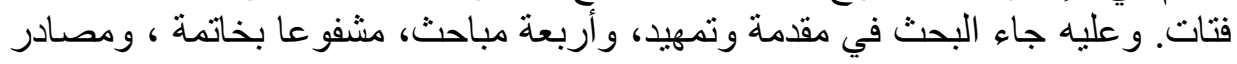

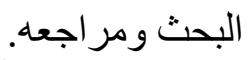
الكلمات المفتاحية: أدب ـ الأوبئة ـ الطاعونـ التراث - مصطلح 


\section{Abstract:}

It is customary for literature to co-exist with the current events that the world is experiencing in influence and influence, and to resonate. and in will not be in vain. he records in memory ingenuity literary masterpieces, and relic artistic texts; a relief of pomp, and an abnormality. And with the aggravation of the virus (Corona) crisis - which souls from it became tired! The year has spoken a lot, The so-called literary and monetary arena has resurfaced By (the term epidemiological literature or epidemiological literature). And that which the poets had told him recorded bitter poetic experiences; in which the size of the agony began, and the cruelty of the scene, The impact of the plague on the environment and society at the time; and describe the magnitude of the tragedy, giving rise to the duty of consolation. From these poet Ali al-Darwish (1796m-1853) and poet Nikola El estambuly (1763m-1828), they each dealt with the epidemic in its poetic production, which struck the country in the eighteenth century ad, In a poetic experience that deserves to be identified and demonstrated, and to know what it has and what it is; to stand on the differences and reach the veins to inspect their March, and to follow their course; a clear manifestation of what has been hidden, Perhaps it is a finger that contributes to the reference to this kind of literature; to collect the diaspora, and the signs that it has written about. Thus, the research came in an introduction, a process, and four points, with a conclusion, sources and references.

Keywords: Literature - epidemics - plague - Heritage - term

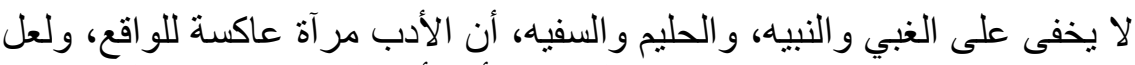

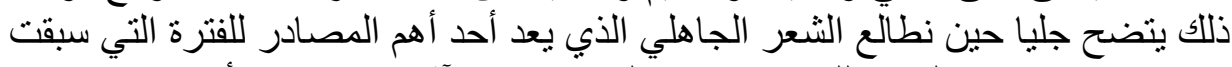

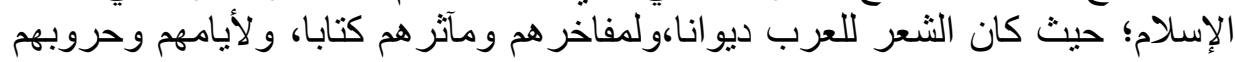




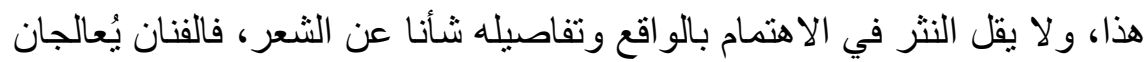

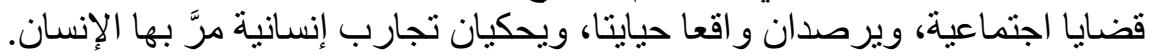

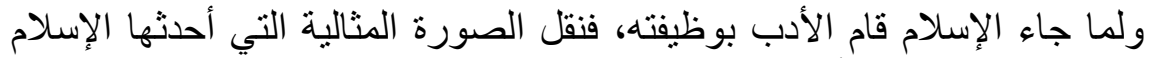

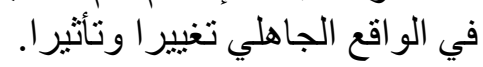

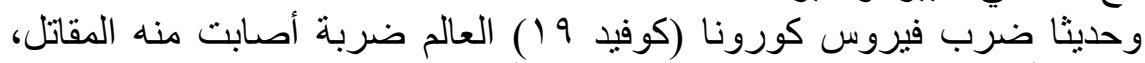

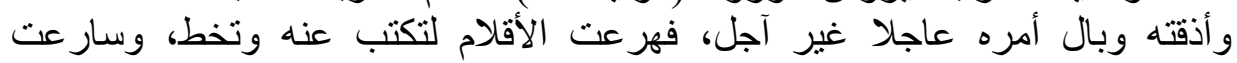

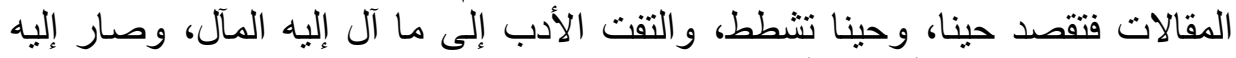

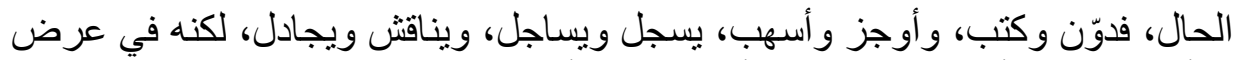

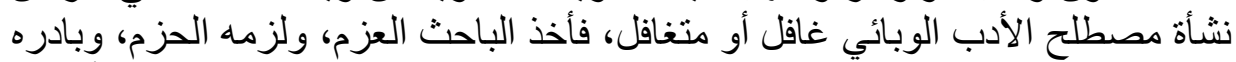

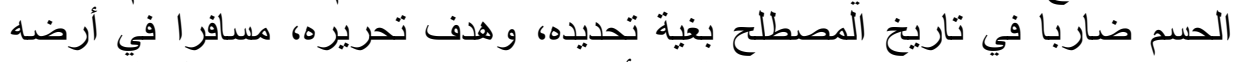

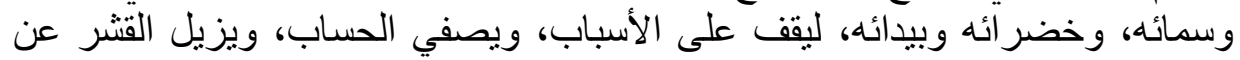
اللباب، مستعينا بالله ..

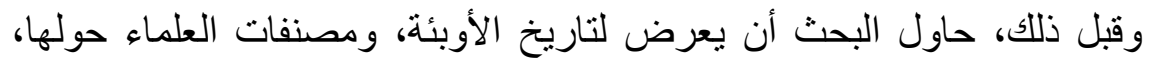

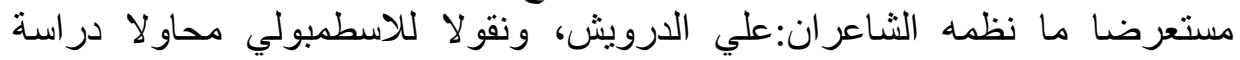
قصائدها في الطاعون وتحليلها.

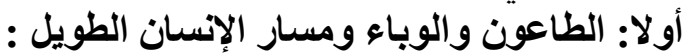

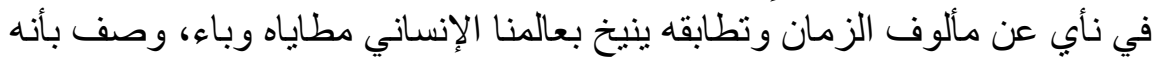

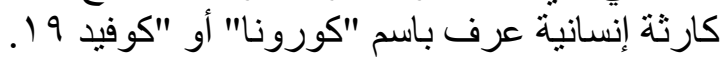

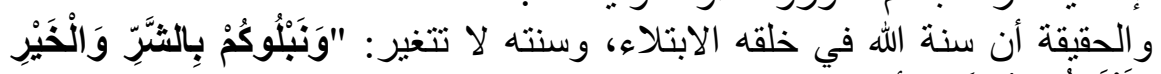

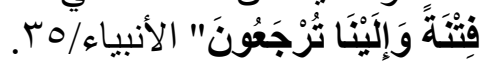

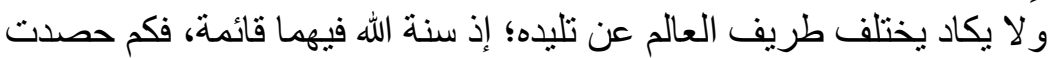

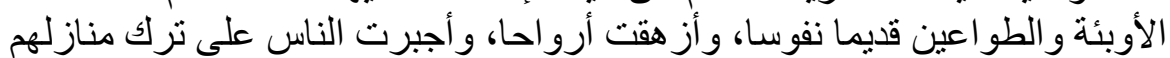

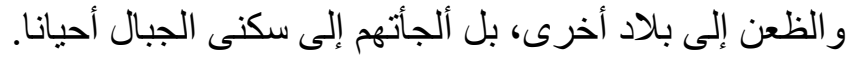

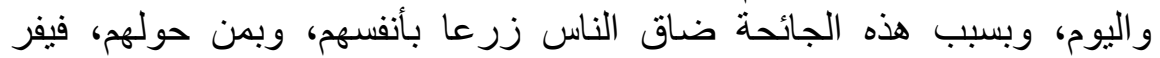
بعضهم من بعض فز عا، وينزوي بعضهم عن بعض هلعا، كالحُمر لاقت قسورة! وصار

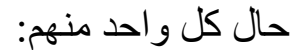

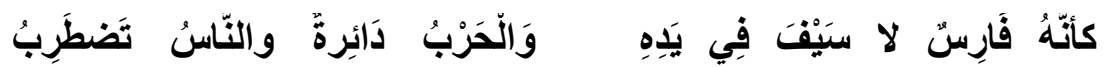

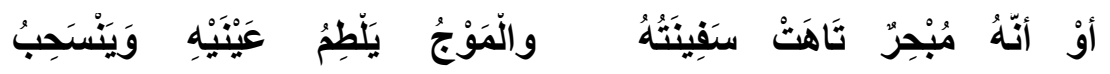

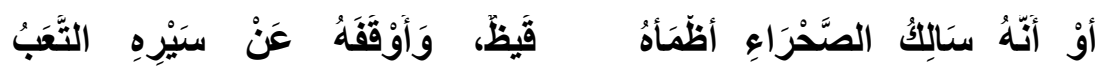




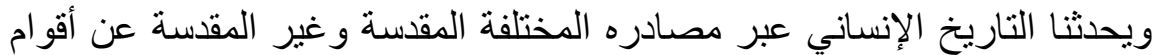
كانو ا أثداء ثم أمسوا صرعى، وأضحوا هلكى، فلا تحس منهم من أحد ولا تسمع لهم الهم الهم

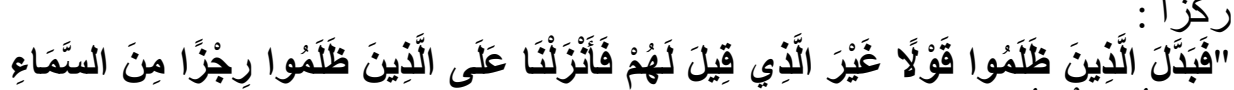

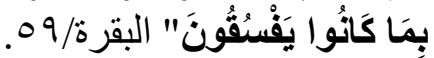

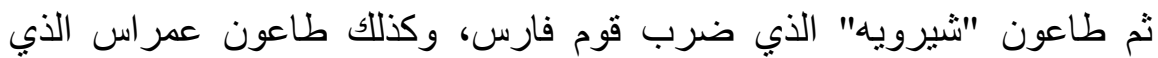

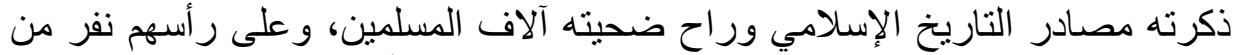

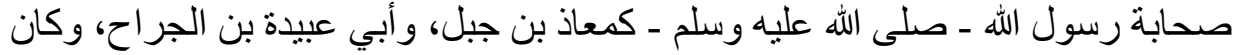

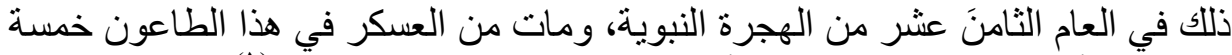

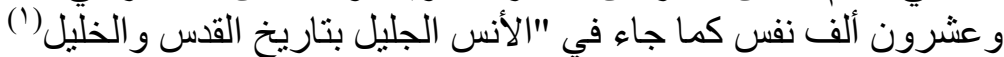

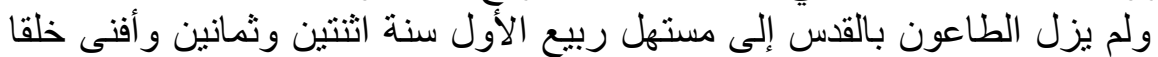

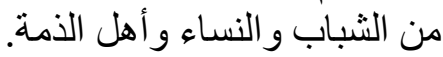
لكننا ومع شدة ذللك الأخذ، وقسوة ذاكة الك الطاعون، سيقف هذا البحث وقات وقفة مغايرة

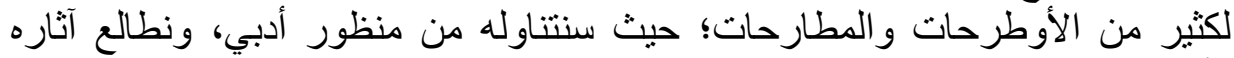

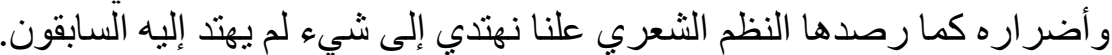

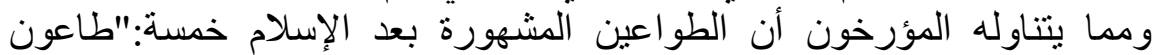

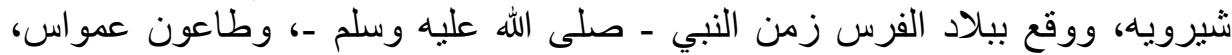

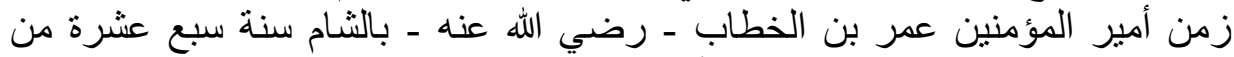

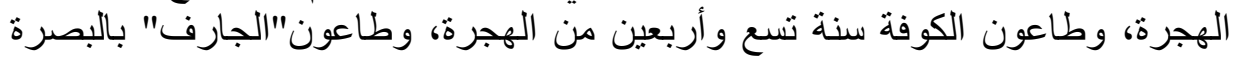

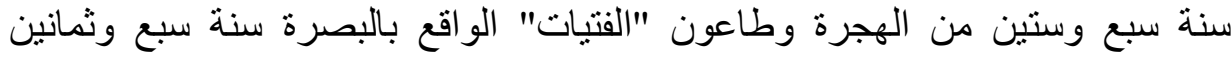

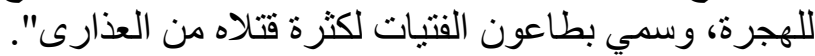
ثانيا: الطاعون في الأدب العربي: لفئي

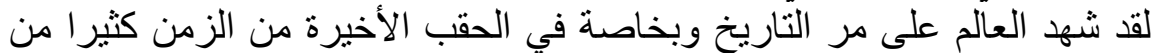

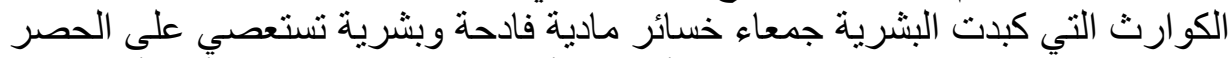

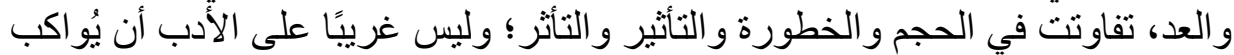

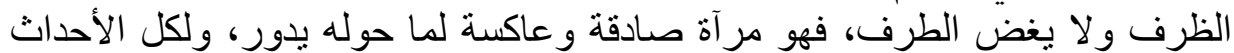

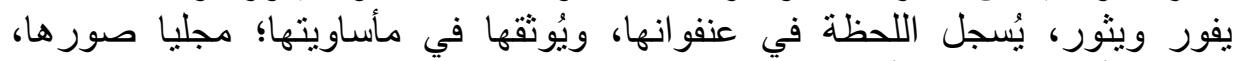

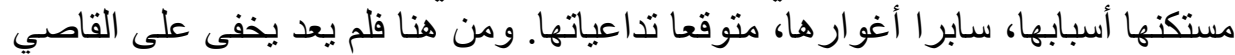

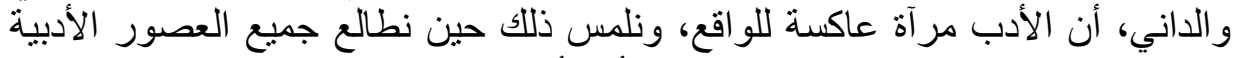

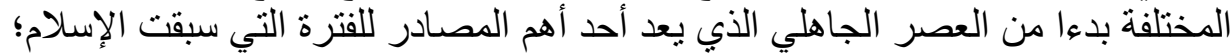

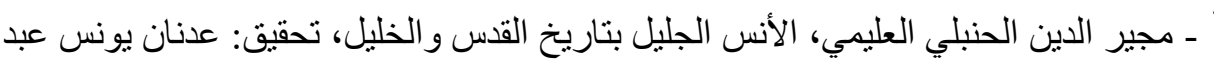

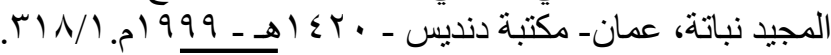


حيث كان الثُعر - وما زال ـ للعرب ديوانا، ولمفاخر هم ومآثر هم قرطاسا وكتابا،

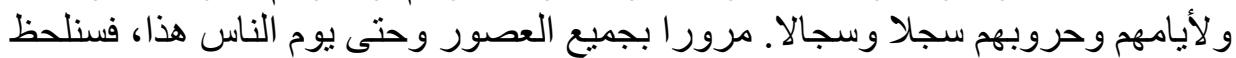

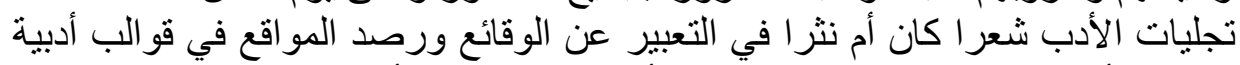

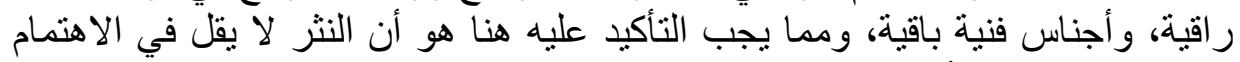

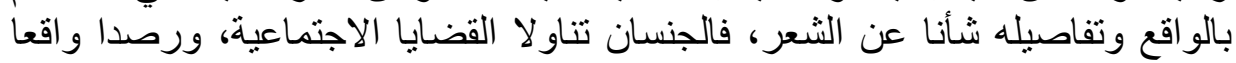

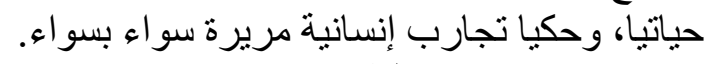

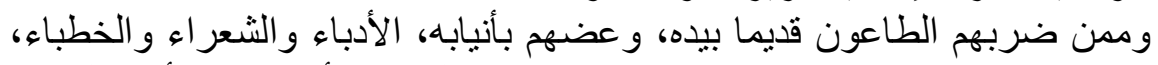

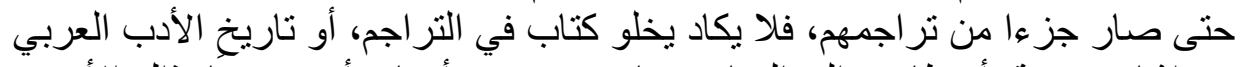

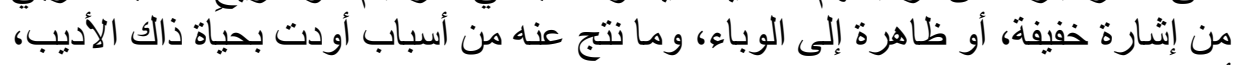
أو هذا العالِّ.

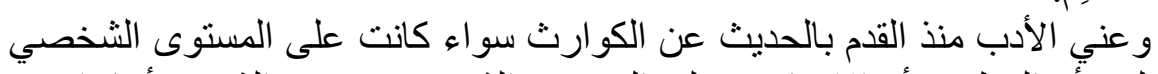

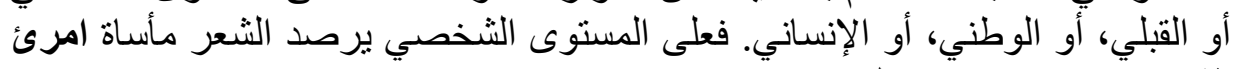

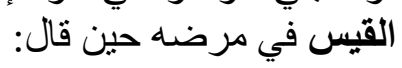

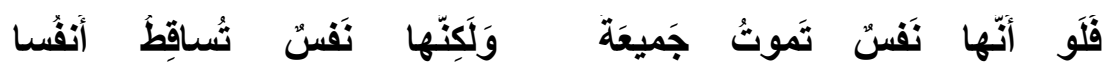

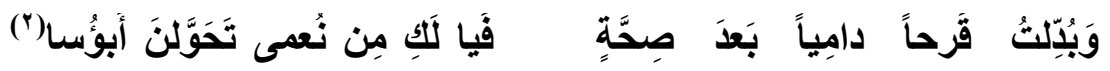

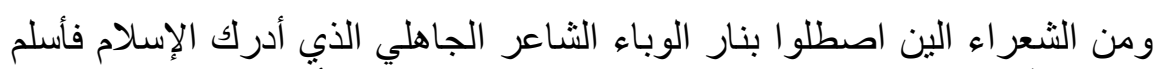

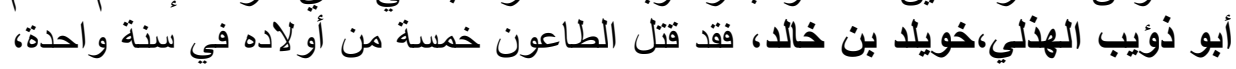

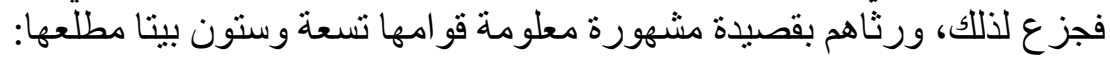

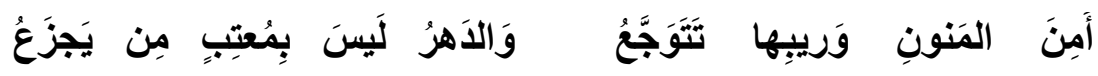

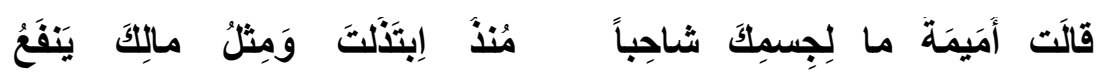

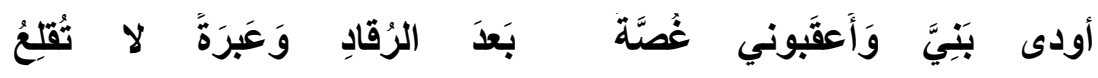

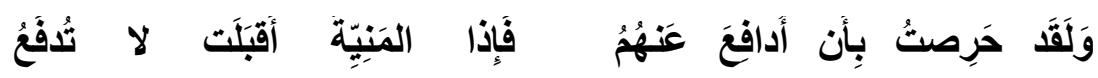

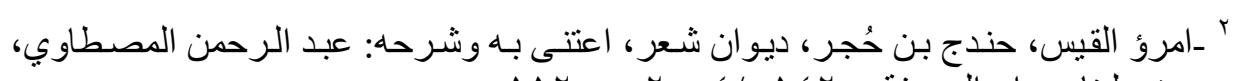

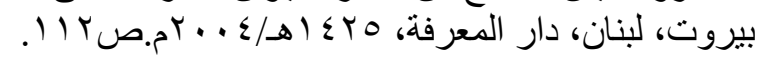




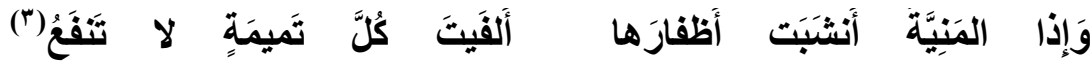
فأبيات هذه القصيدة جرت على ألسنة الناس مجرى الحِكم إلى اليوم فهي مشحونة

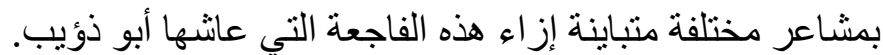

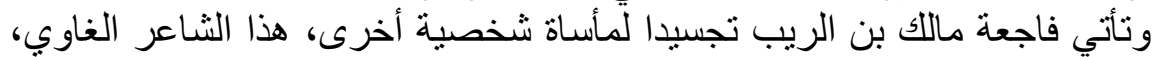

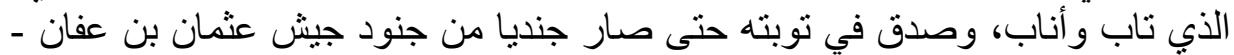

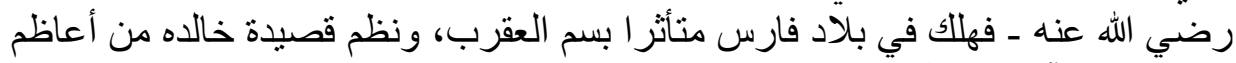

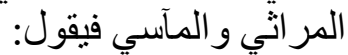

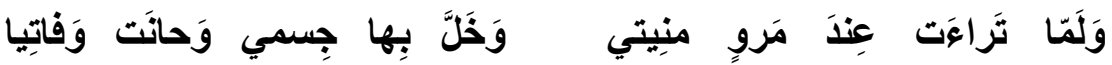

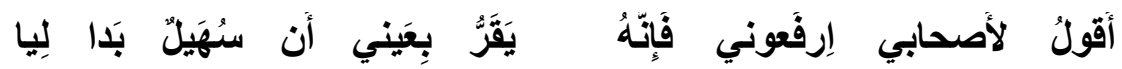

فَيا صاحِبي رَحلي دَنا المَوتُ فَانْزِلا وذاق مرارة هذه الكاس المترعة بالموت أبو الأسود الدؤلي اللغوي، فقد مات ألات

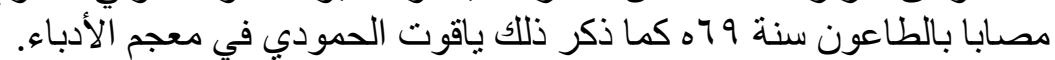

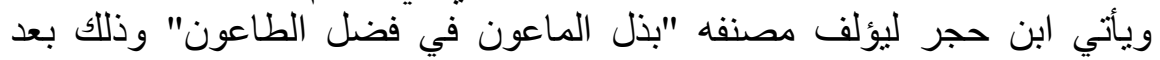
أصابت يد الطاعون ثلاثا من بناتها.

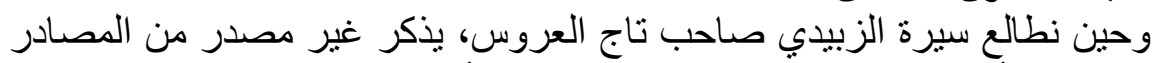

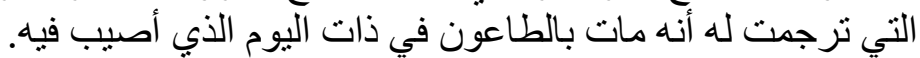

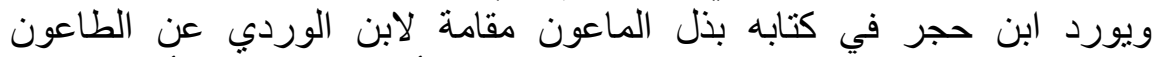

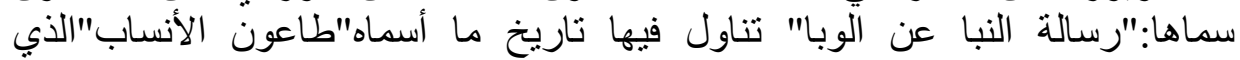

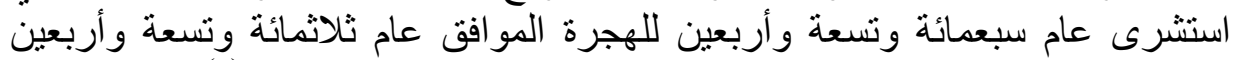

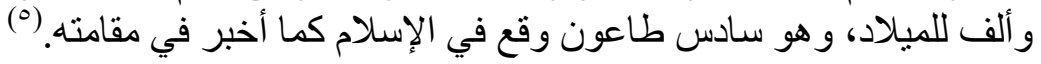

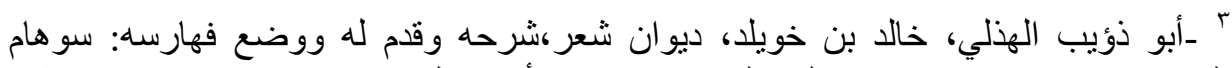

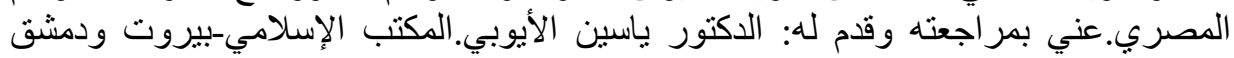

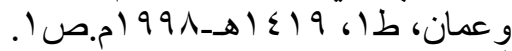

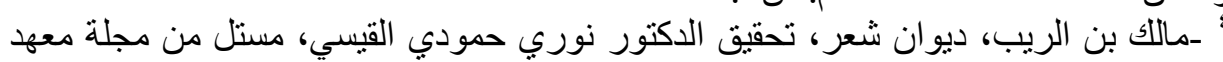

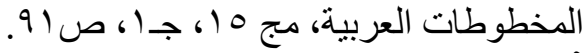

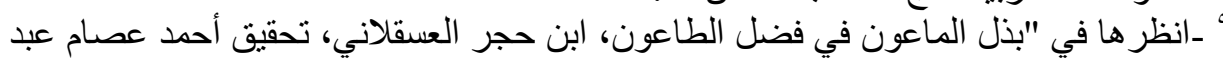

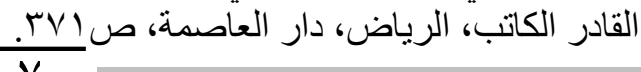




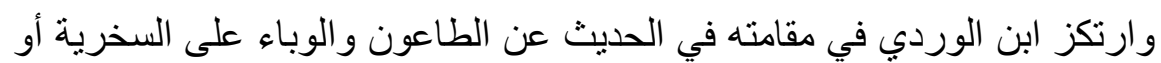

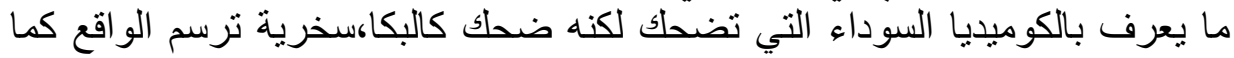
هو ،وكما تراه عينه هو لا غيره، فهما في الحقيقة واحد لا الثنين، فهما في واقعية الروئية

سخرية ابن الوردي في مقامته سخرية شاملة، يمازجها نوع من والتناص المتحرر

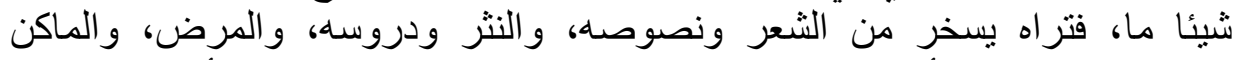

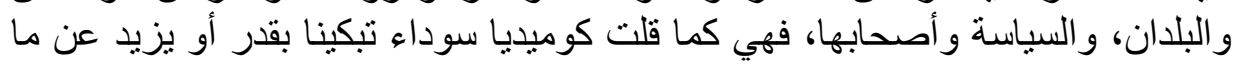

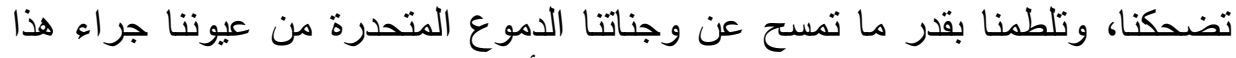

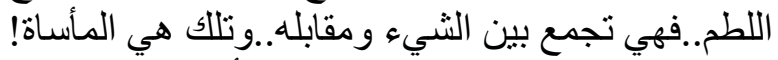

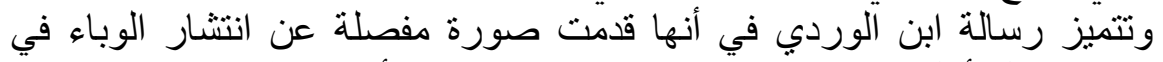

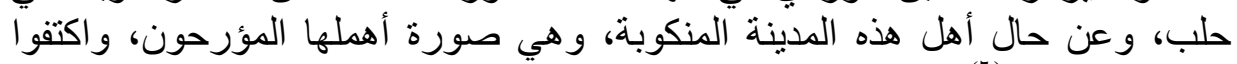

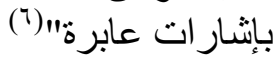

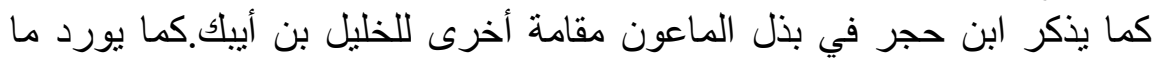

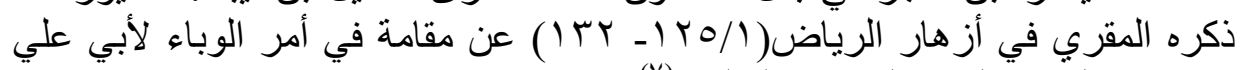

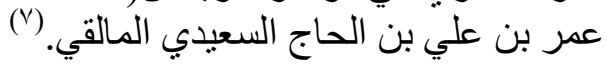

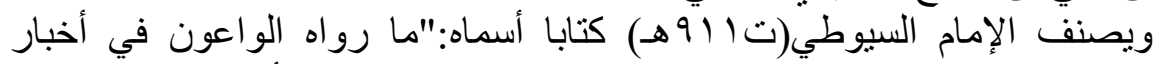

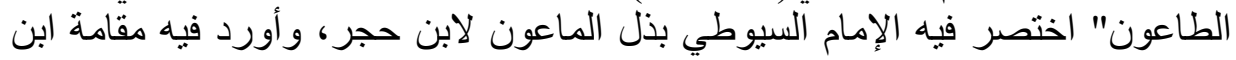

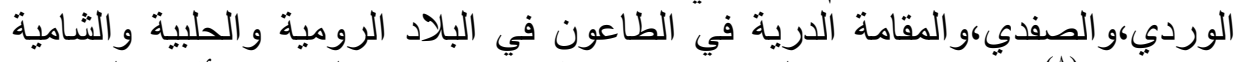

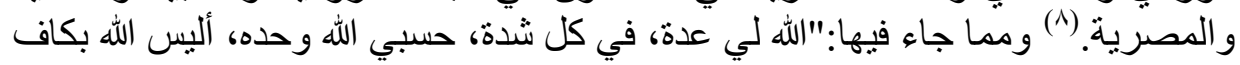

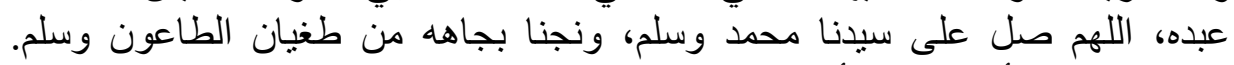

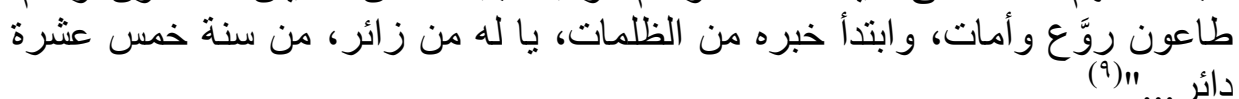
وذكر الخطيب ابن نباتة عبد الرحيم بن محمد (تى كrهـ) خطبنين في ذكر الموت

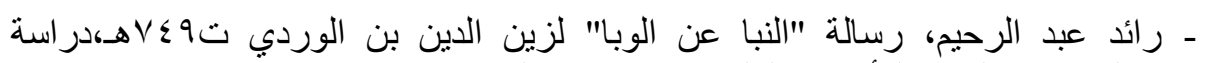

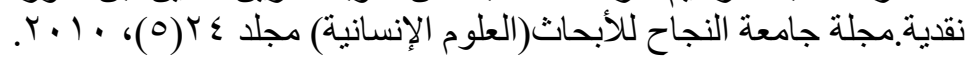

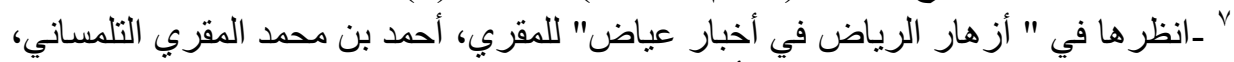

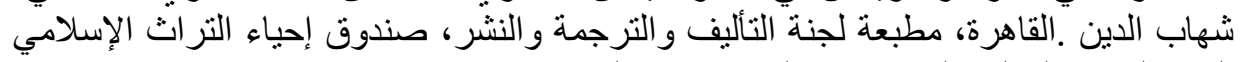

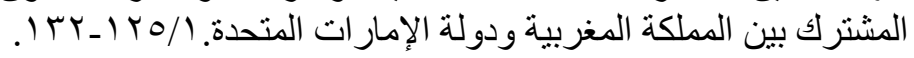

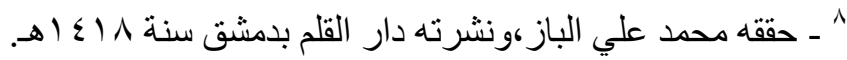


والوباء في ديوان خطبه. (·) وصنف المقريزي كتابه"إغاثة الأمة بكثف الغمة، وذكر فيه كثير ا من المصائب التي نزلت بالناس في أزمان متفرقئه والآية من هذا كله أن ما يظهر من فئنة فيروسات وأوبئة في مسار الإنسان الطويل

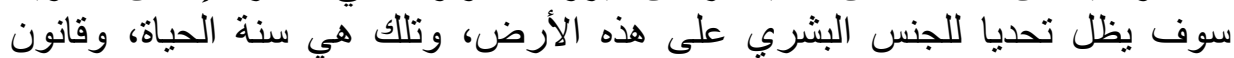

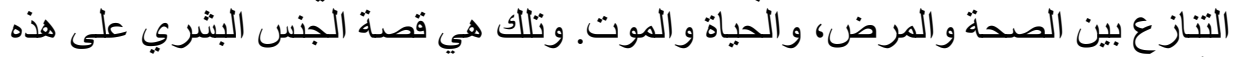
الأرض.

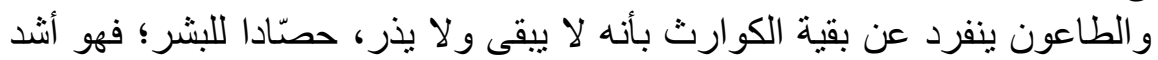

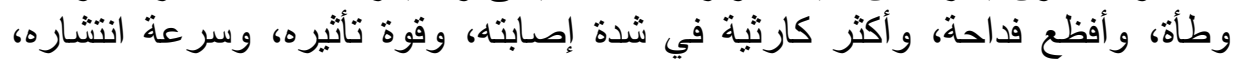

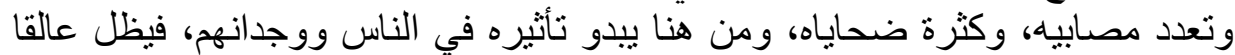

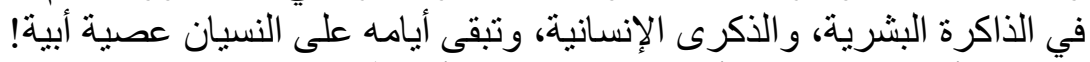

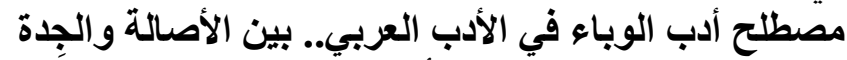

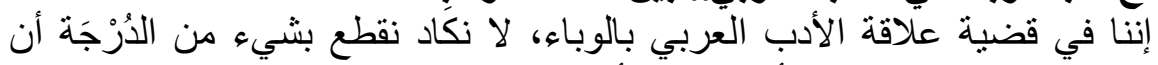

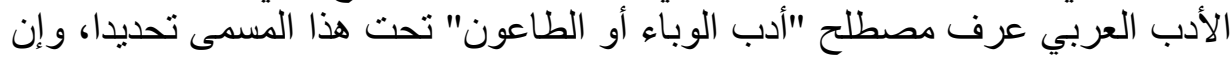

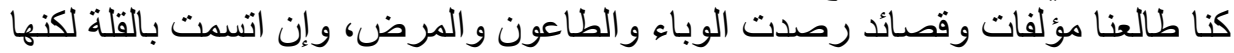

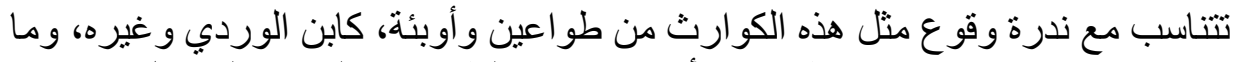

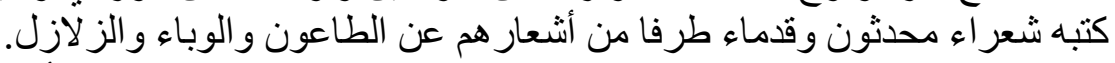

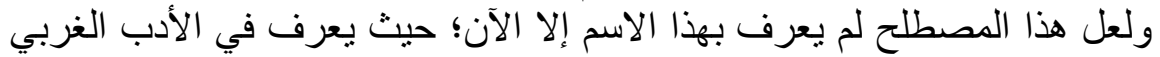

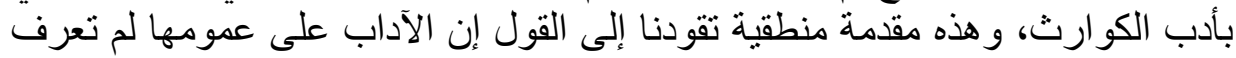

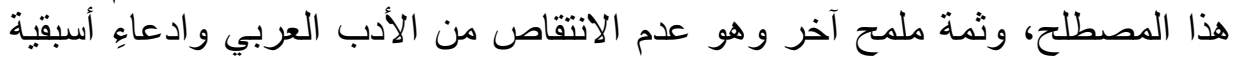

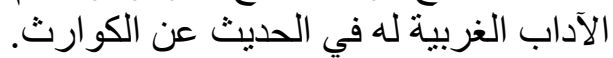

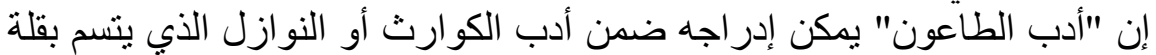

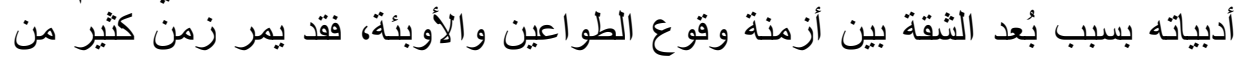

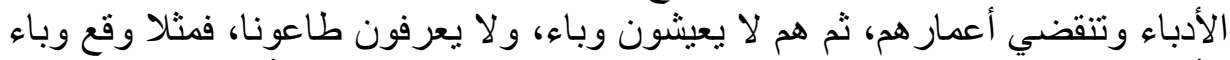

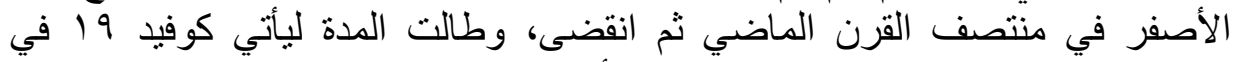

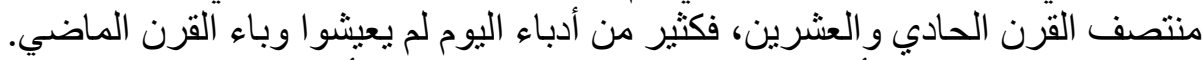

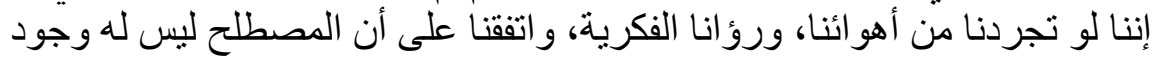

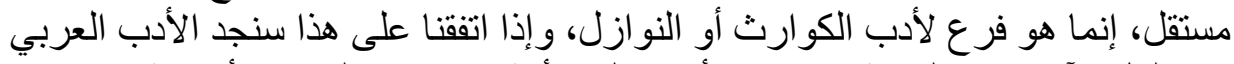
سيدا لكل الآداب في الكتابة عن هذا الأدب. فليس أكثر منا نحن العرب مأساوية!

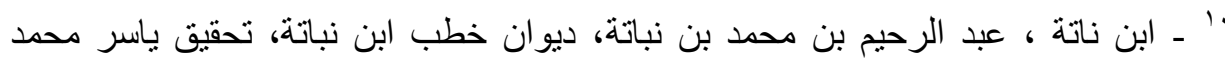

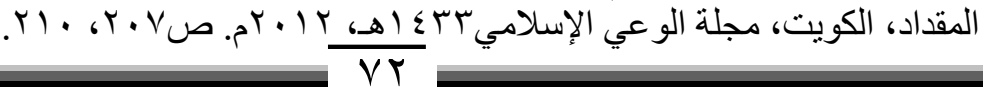


ألم يكتب الثُعراء في سقوط ممالك الأندلس و إمار اتها؟ ألم يصف أبو البقاء الرندي تلك الكارثة التي حلَّت بيلاد المسلمين قاطبة، عمومها دون آحادها، فقال:

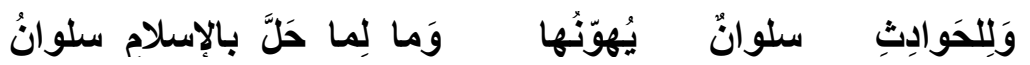

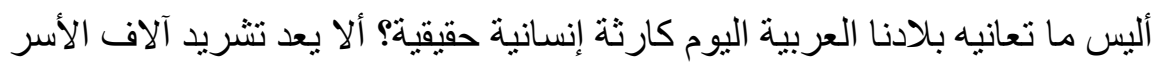
وتهجير ها من بلادها، و هلاك كثير منهم جر اء هذاء هذا التهجير:

مآسي الثام لم يشها، مثيلا

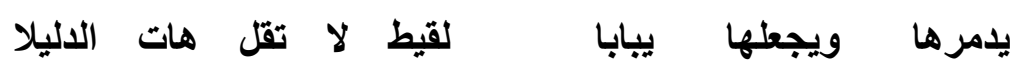

إن الباحث على بينة وبصيرة من أن كل ما يعانيه الإنسان في خاصة حياته، و وعامة

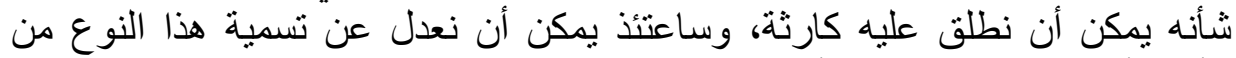

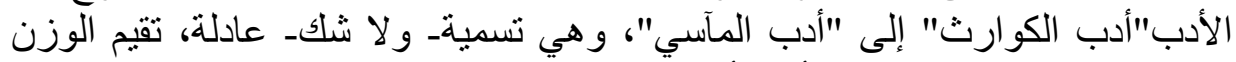

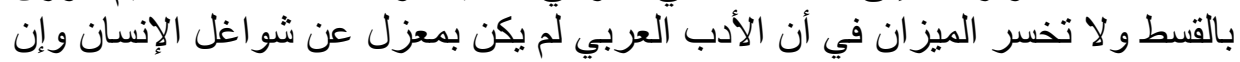
اتخذت هذه الثو اغل، وتلك الدو اهي التي مسميات حديثة. ويتأكد هذا الر أي حين نطالع قصيدة عنترة بن شداد:

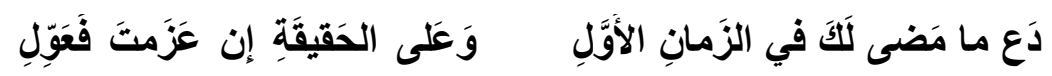
و هي قصيدة يعرض فيها مأساته الثخصية، وما سبيته له من ألم نفسي، بلغ به أن

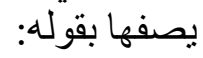

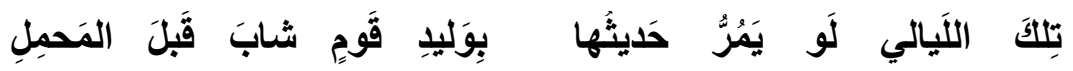

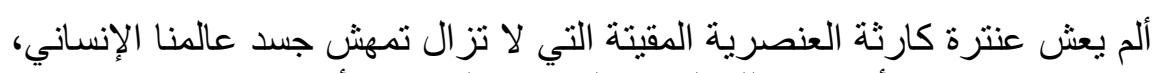

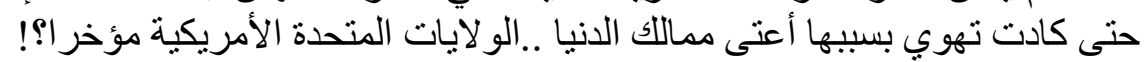

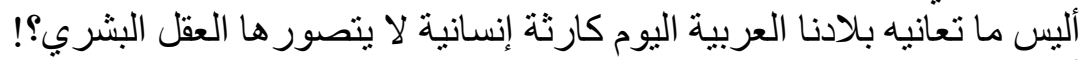

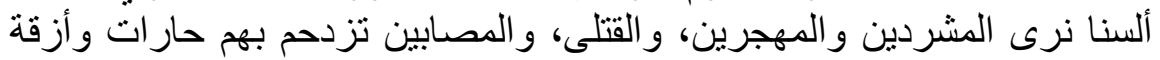

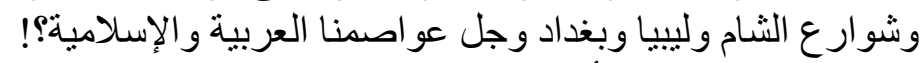

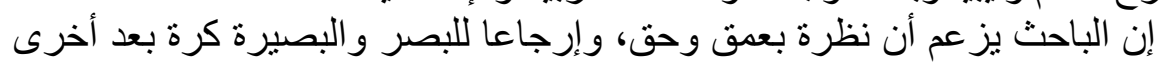

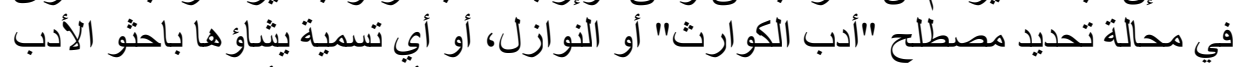

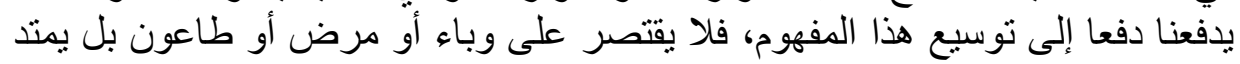

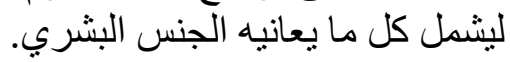


ثالثا: حياة علي الدرويش ونقولا الاسطمبولي .. لمحات و إشارات:

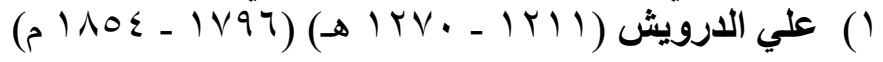
•اسمه ونسبه:

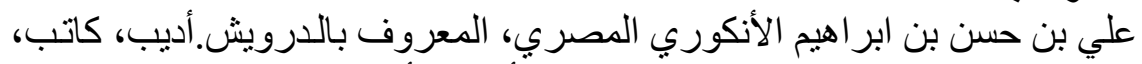

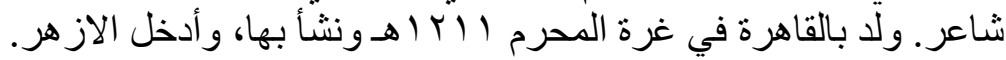

أخذ عن الثيخ المهدي و القويسني و الصـاوي و غير هم، ثم مالت نفسـه إلى الأدب

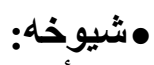

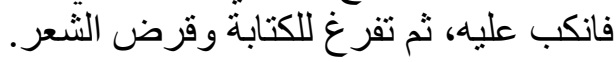

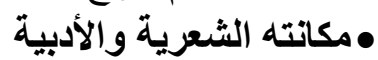

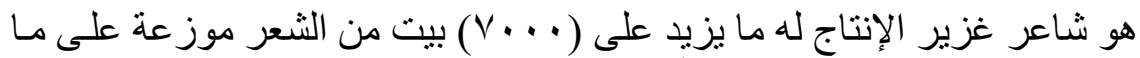

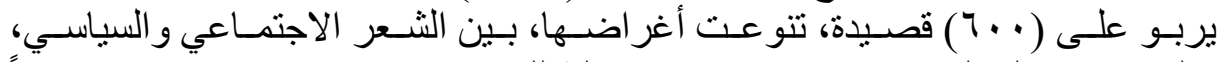

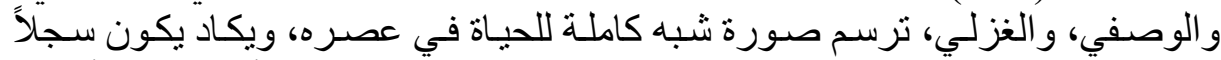

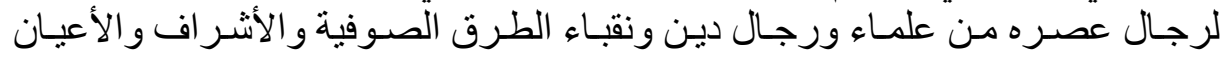

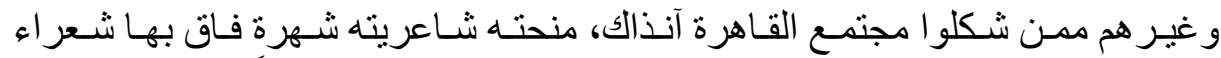

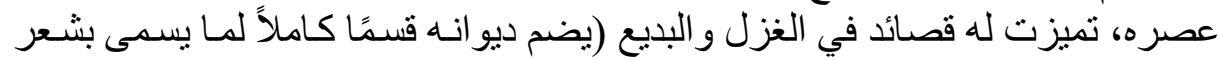

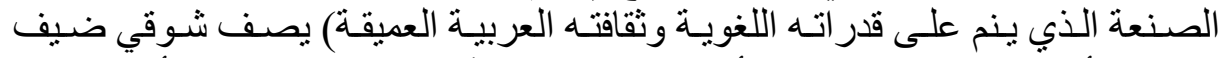

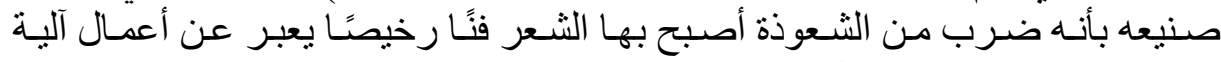
وتمارين هندسية صعبة الحل. •وفاته: وتمارين

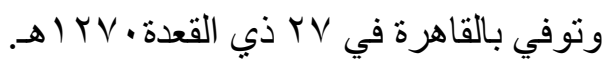
• آثثاره:

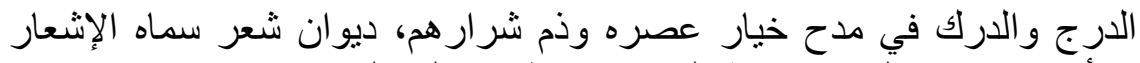

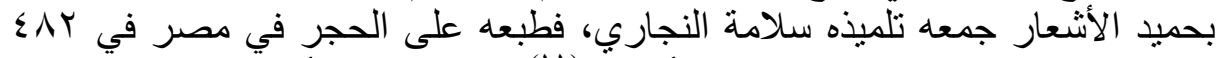

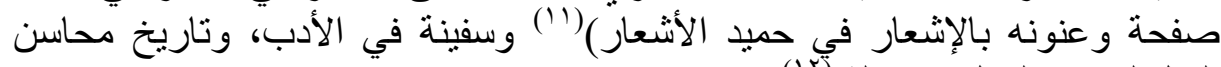

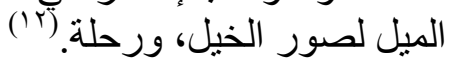

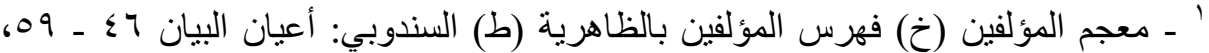

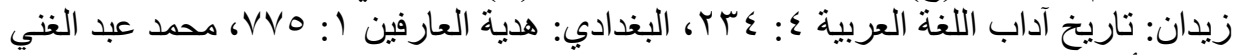

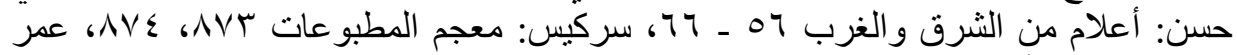

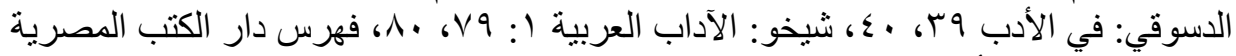

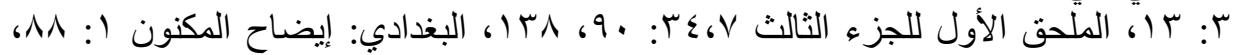

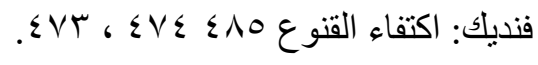




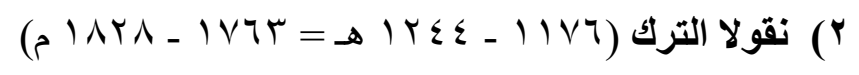

اسمه ونسبه:

نقو لا بن يوسف الترك، ويقال له الاسطمبولي: ولد في الحقبة التي شهدت مظاهر

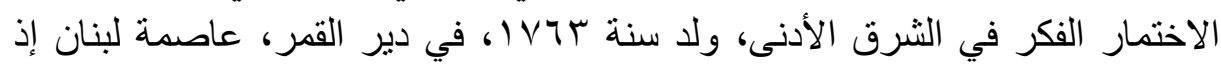

ذالك.شاعر، له عناية بالتاريخ. انتقلت أسرنه اليوناينية الأصل، القسطنطينية المنشأ، إلى الكتلكة في أوائل القرن

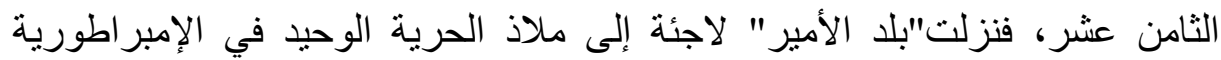

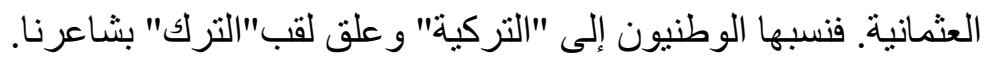

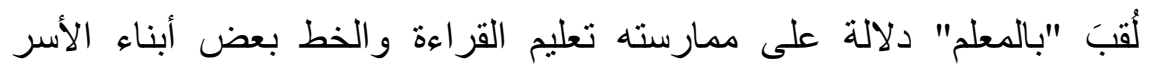
الارستوقر اطية.

سافر إلى مصر واستخدم كاتبا في حملة نابليون الأول. وعاد إلى لبنان، فخدم

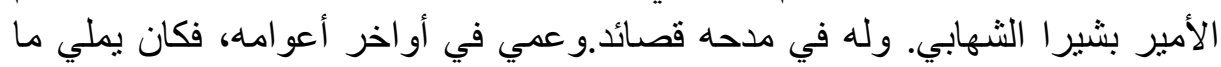
ينظمه على ابنته وردة.

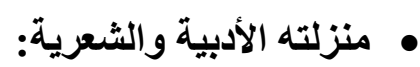

جاء ديو انه "وقد رافق حياته الخاصة والتهائة والعامة، محتويا على نحو خمسمائة قصيدة

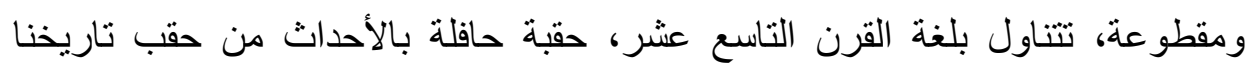

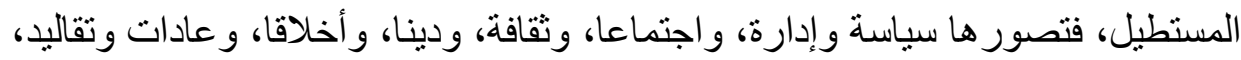

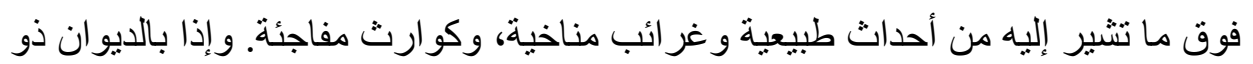

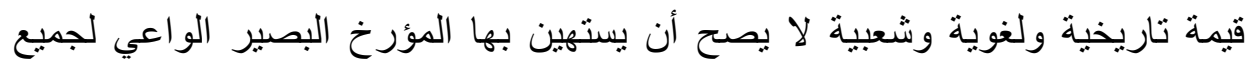

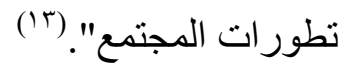

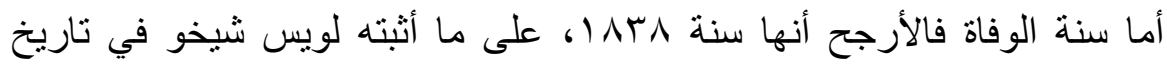

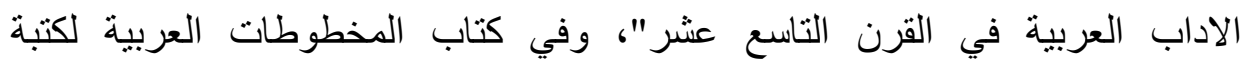

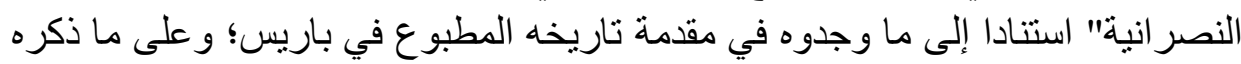

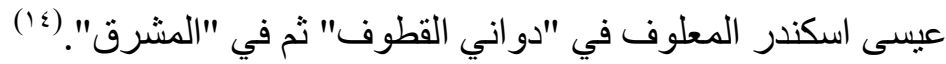

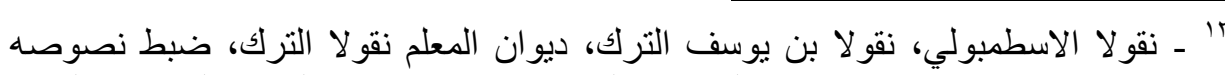

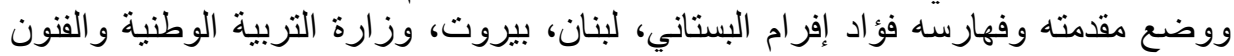

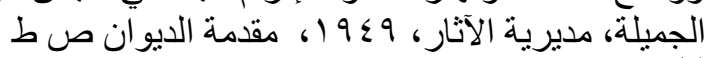




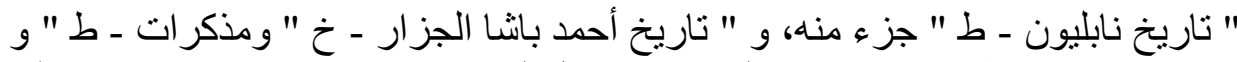

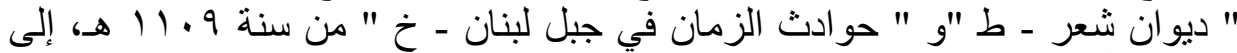

(10) (10) ب 10

الطاعون في شعر علي الدرويش ونقولا الترك..دراسة وتحليل

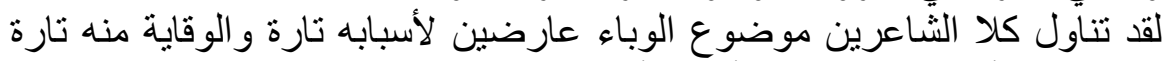

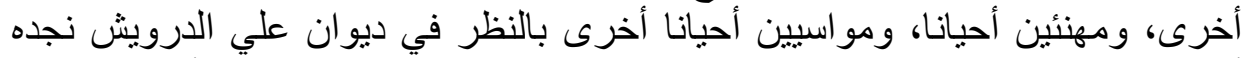

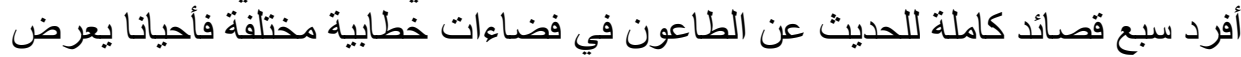

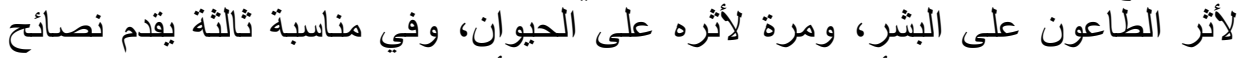
يتوجب على المنصوح الأخذ بها للنجاة، وفي قصيدة الخئ على أخرى يهنئ بذهاب الطاعون، ومرة

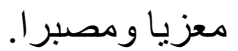
في القصيدة الأولى وقوامها تسعة عشر بيتا، فال مخاطبا بعض الأعيان الذين أصاب الطاعون بهائمهم في قصيدة مطلعها:

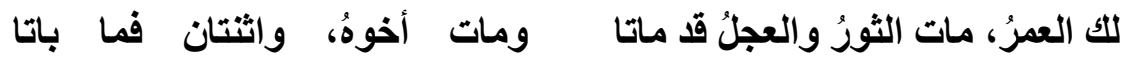

تعيش وتبقى حيث ماتت بهائمي ونظٌُ دراري عقدِها صار أشتاتا

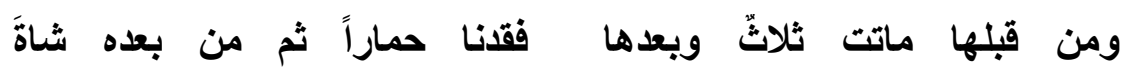

كسيارة السبع الطباق طوالعاً مجرتها تزهو بها صرن أمواتا

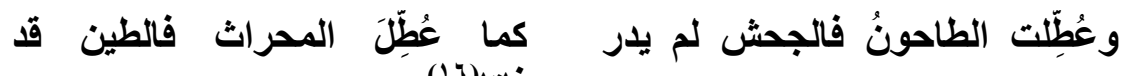
و هي قصيدة دعابية ساخرة، تخلو من الشعور بالأسى، والإحساس بألم الطاعون؛

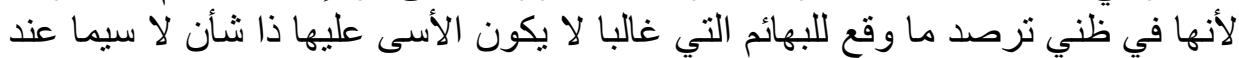

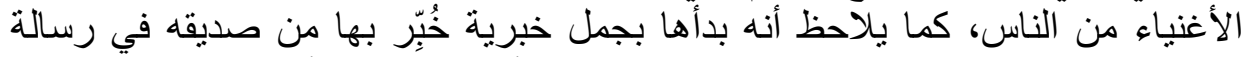

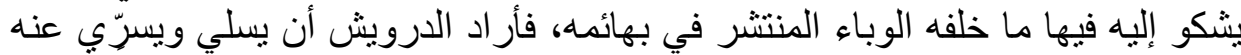

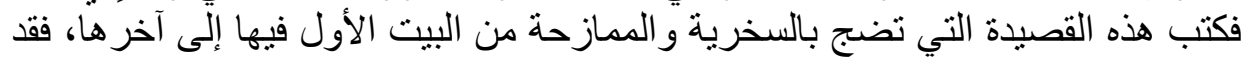

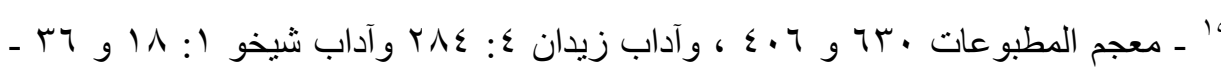

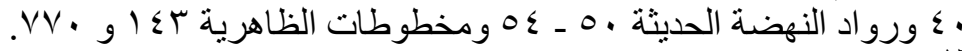

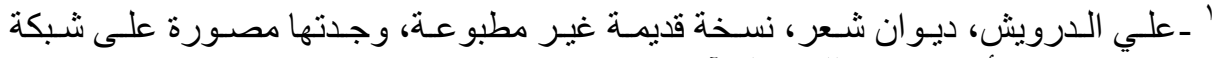

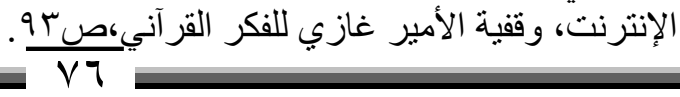




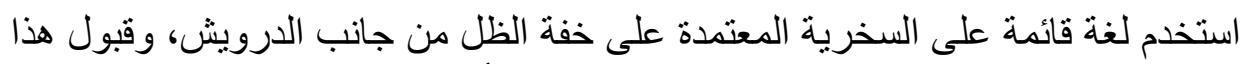

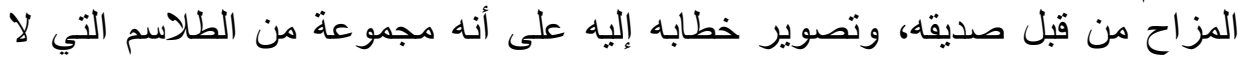

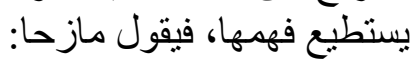

أتاني كتابٌ منك فوراً أخالَهُ كنثرِ وطوراً أحسب النثر أبياتا

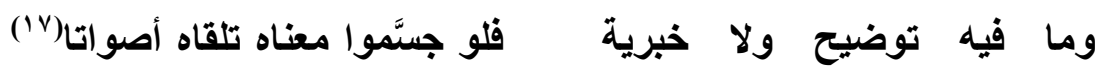

ثم يختم قصيدته ببيت فيه دعاء يحاول من خلال إز احة ما في نفس صاحبه من آثار

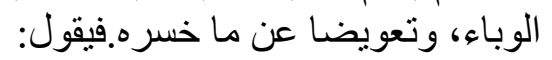

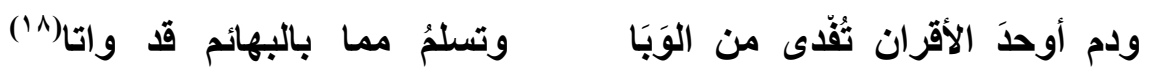

وفي قصيدة أخرى يبين فيها أن سبب الطاعون الذي ضرب بهائم الأعيان ألعان إنما هو

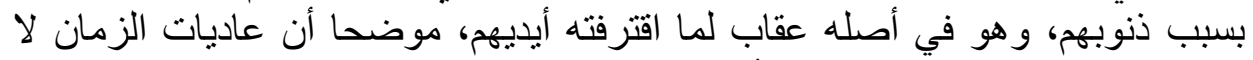

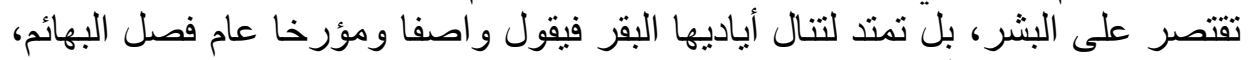

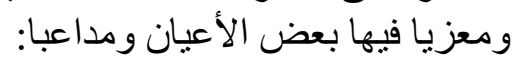

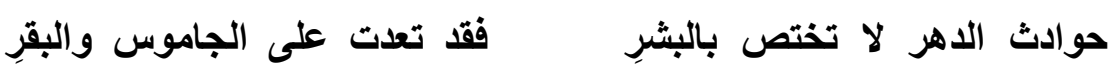

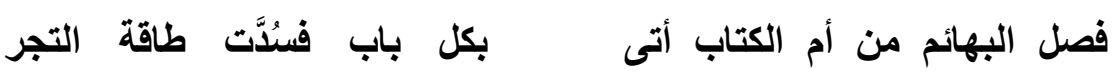

فصل البهائم من أم الكتاب أنى بكل باب فسيَّت طاقة التجر(19) إنها الأقدار التي لا يمكن تغييرها، وليس بالإمكان تفسير ها، على حد قول باب

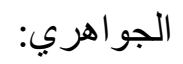

تجري على رسلها الدنيا ويتبعها رأي بتعليل ومعتقد

أعيا الفلاسفة الأحرار جهلهم ماذا يخبي لهم في دفتيه غُ

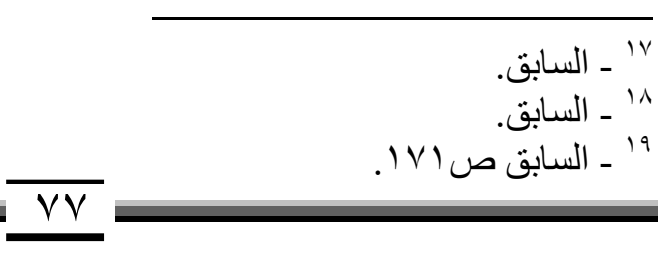




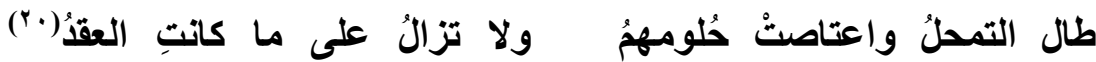
ويؤكد الدرويش على ضرورة الإيمان بالغيب، وتقديم مشيئة الله على كل مشيئة،

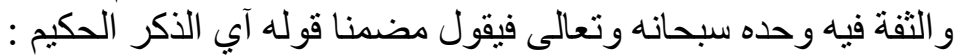

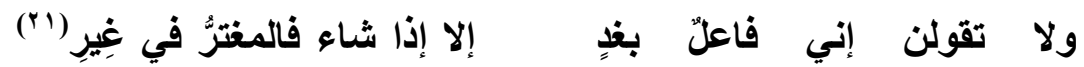

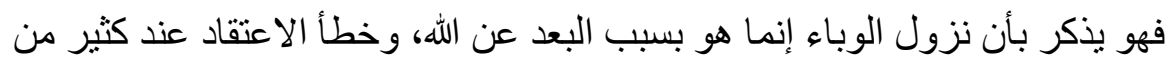

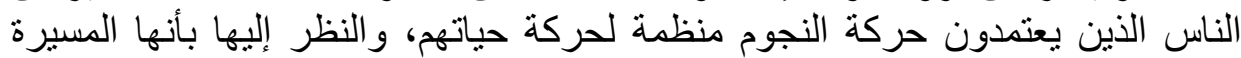

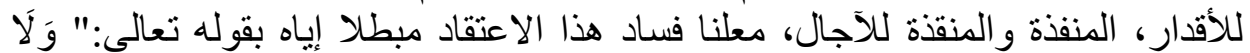

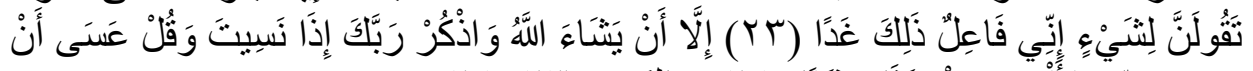

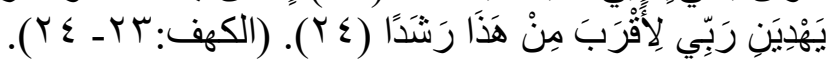

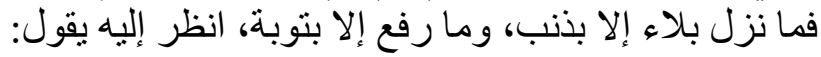

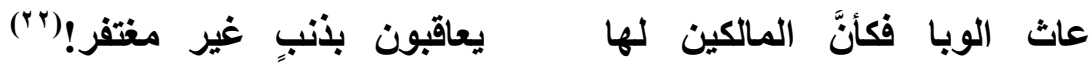
لكن، ومع هذا فكل شيء بقدر، وكل حي له أجل، وكل شيء عند الله مكتوب، فالتسليم التسليم، والرضا الرضا، هكذا يدعو الدرويش من ابتلي في بهائمه أو حنى في في نفسه:

يا أيها الشيخ لا تغضب لما فعلت بها المنون ولا تهرب من القدر

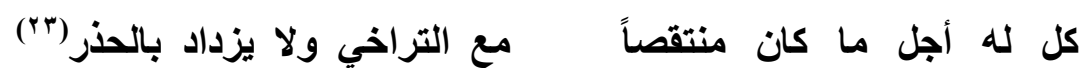

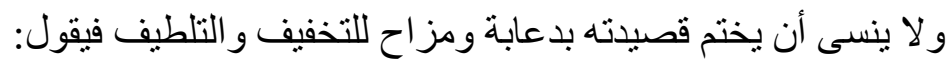

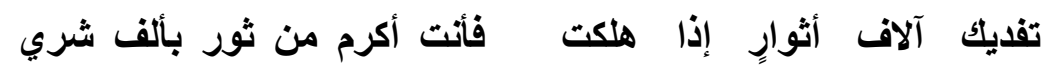

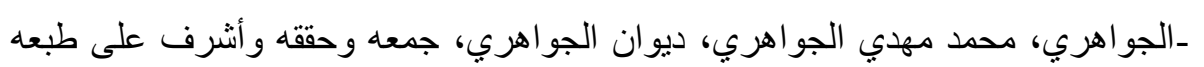

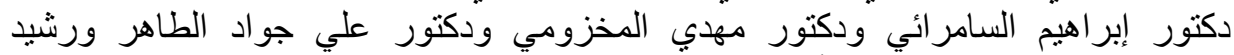

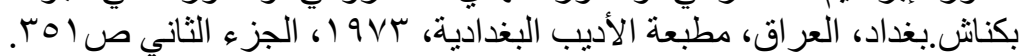

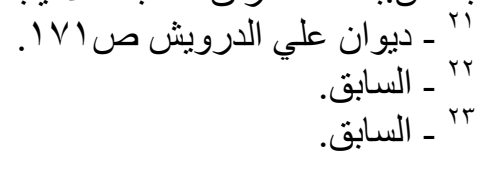


كلاكما خلفُ عن فقد صاحبه إن صار مبتدأ لذلك الخبرِ

لا نال جلاك في الدنيا أساكفة ولا تخنك يد السلاخ بالشفرِ(؟) وثالث قصائده في الوبا، إنما هي نصائح و إرشادات فيما ينفع أيام الوباء، حاول فيها الدرويش أن يقدم نصائح طبية، وإرشاديات إنهات وقائية في اثثتي عشر بيتا مطلعها:

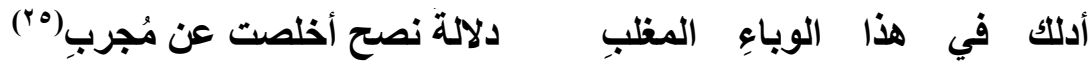

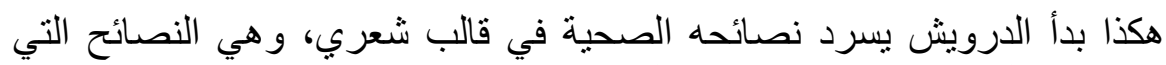

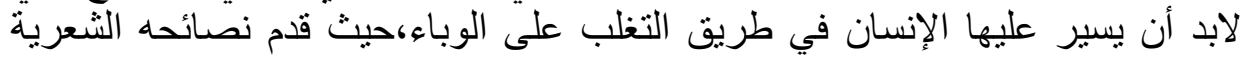
كالآتي:

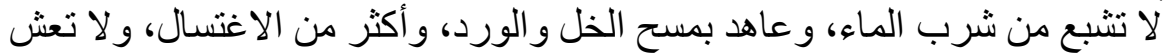

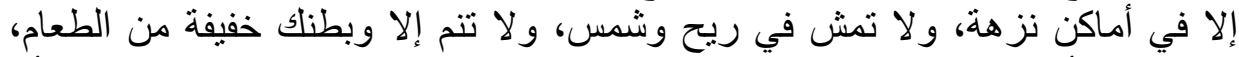

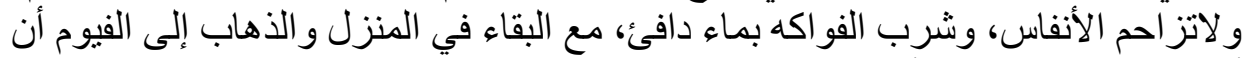

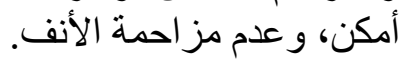
إنها نصائح غالية كما يصفها هو ، من اهتدى إليها حمى نفسه وأهله من هذا الوباء

إذا شاء ربي واهتديت لها فقا وأول هذه النصائح أن يحرص على شرب الماء الزلال ويتضلع بما عذب منه:

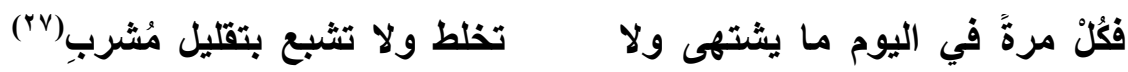
ثم يوصي بأكل الفاكهة المغسولة بماء الخل و الورد:

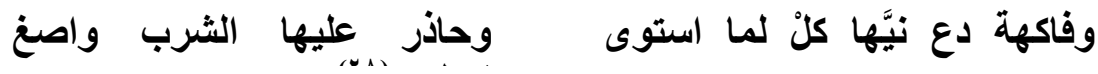
و لا نعش إلا في أماكن نز هة، ولا نمش في ريح وشمس:

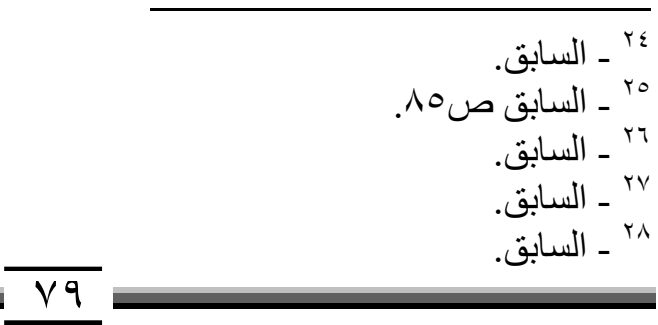


وعاهد بمستح الخل والورد واعتكف عن الغـيظ والقيـظوعـن كل مُتعـب ولا تمش في ريح وشمس ولا تطل وإن ألزمَتْْ في الصبح والعصر فاركبِ(9) كما يتوجه بالنصح في التخفيف من الطعام قبل النوم، لتخرج الأنفاس وتدخل

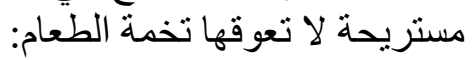

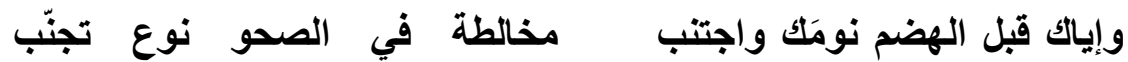

مزاحمة الأنفاس تفسد بعضها وهل تفس النيران غير المقرب(") ومن وصاياه: الزم الأماكن النظيفة، واخرج إلى الحدائق، وداوم على غسل اليدين وجميع الحواس:

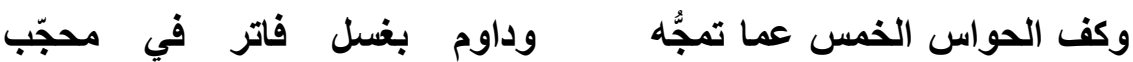

ولا تبق إلا في أماكن نزهةٍ منزهة عن مكرهات ومترب('اب) و ولا ينسى أن يؤكد أن هذه النصائح إنما جاءت من بصير مجرب، وأن الله خلق

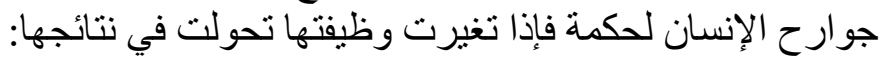

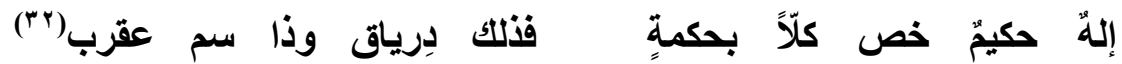
تلاك كانت نصائحه المخلصة التي تتماثى مع نصائح الطب الحديث الآن المرشد

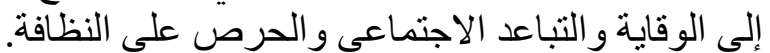

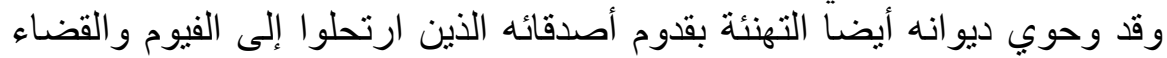

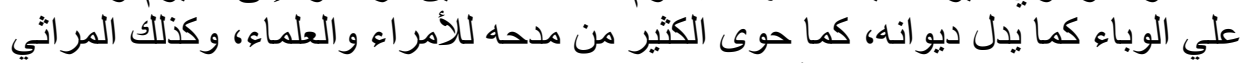

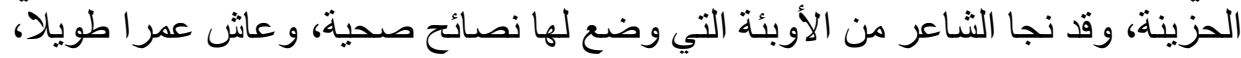

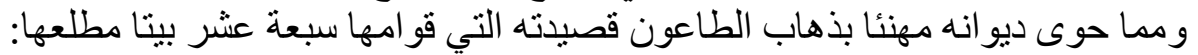

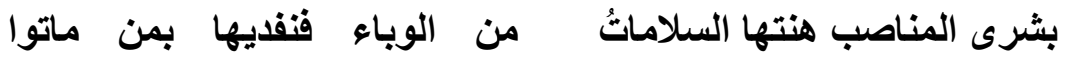

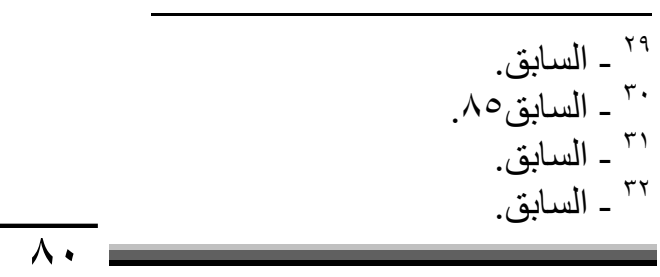


عام مضه/ فيه راعتنا مصائبه وجاء عامٌ مضت عنه المصيباتُ

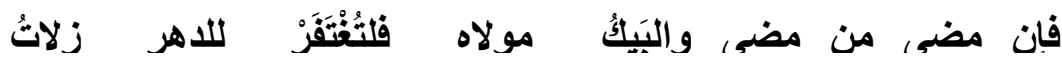

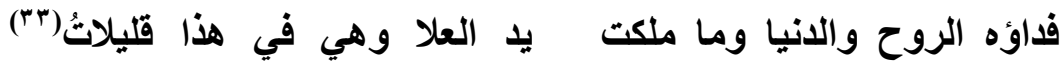
وفي قصيدته الخامسة يهنئ حضرة نقيب السادة الأشر اف المرحوم السعيد البكري بذهاب الطاعون

نهني النفس بشرى بالنجاةِ من الطاعون أدهى المدهماتِ

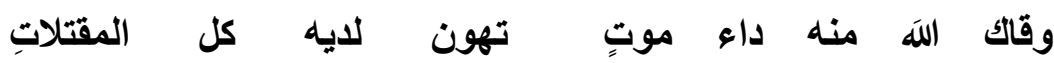

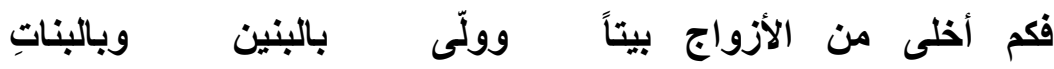
أعذتك منه باسم الله لما سقى الأرواح كاسات المماتِ إذا سلمت بنو الصدّيق منه فليس بمشكل في المشكلاتِ(«)

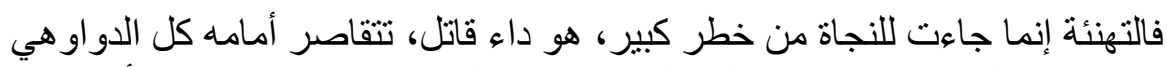

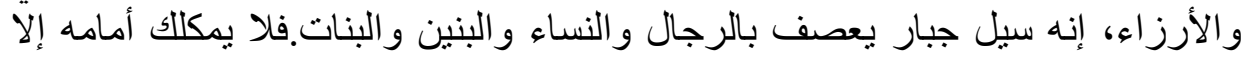

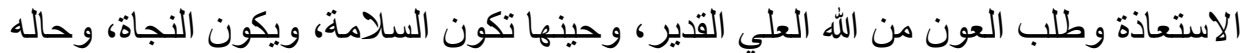
حال المتنبي حين قال:

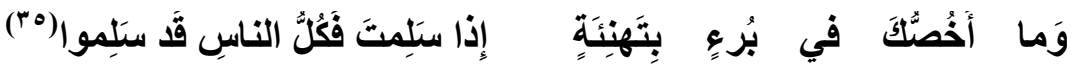

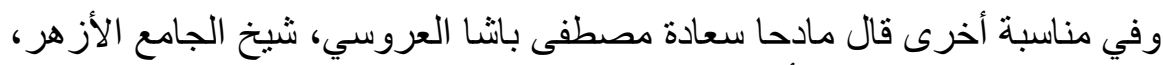

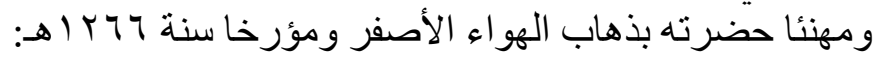

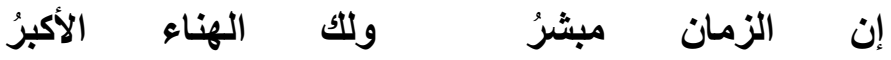

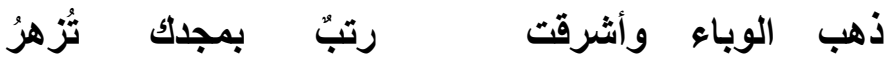

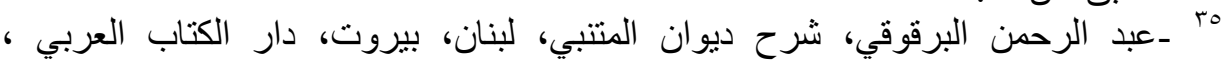




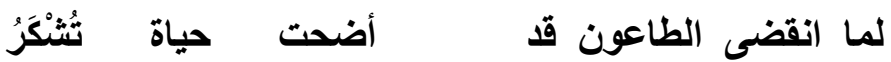

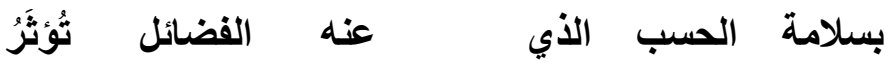

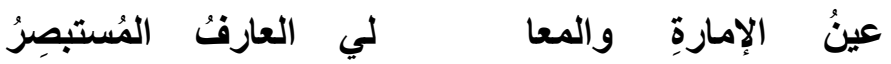

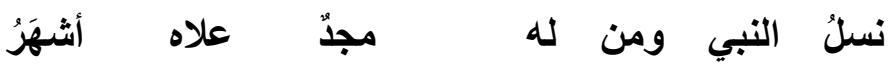

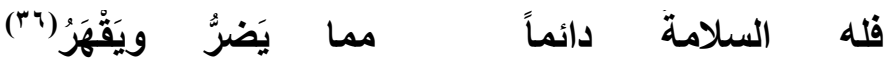

أما قصيدته الأخيرة فيمدح فيها "غيطاس أفندي الروزمانجي" ومهنئًا له بذهاب

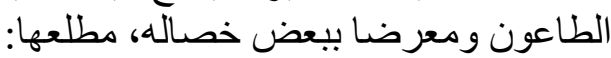

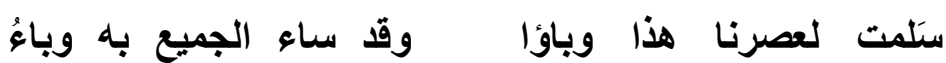
وستَامحنا الزمان بما جنَاه إذا غيطاس كان له البقائُ

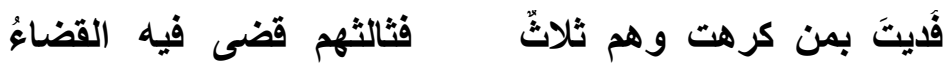

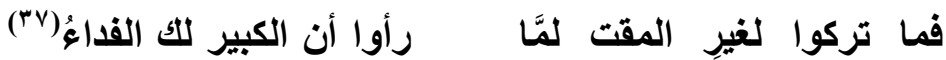

الوباء في شعر نقولا الترك:

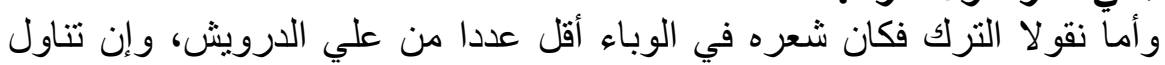

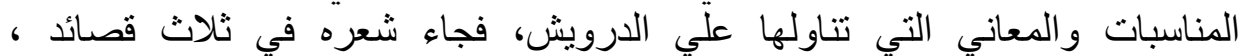

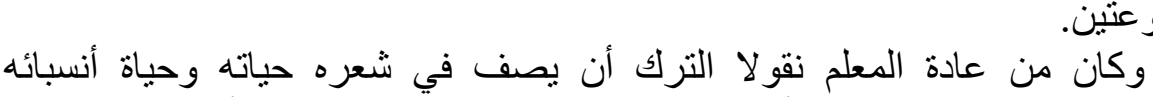

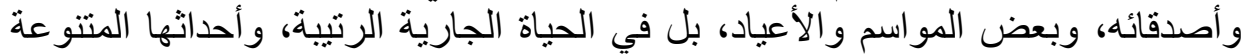

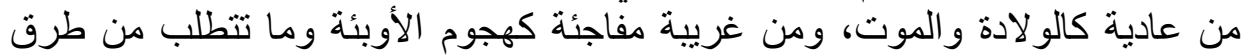

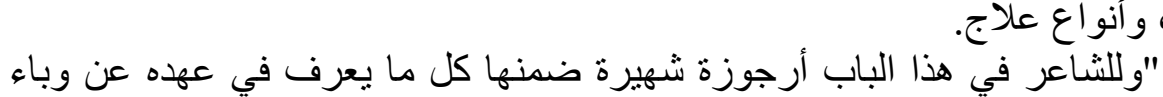

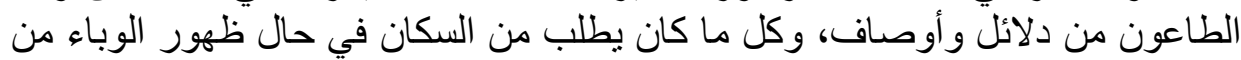

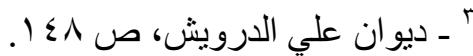

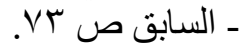


احتياط و اهتمام، مستعملا الألفاظ الوضعية و المصطلحات الخاصة، مما يجعل للأرجوزة

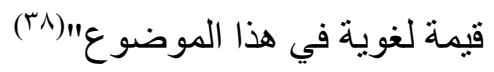

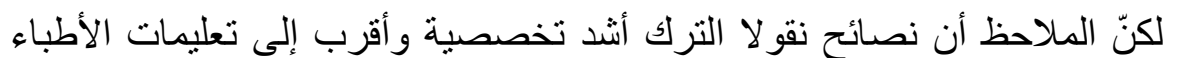

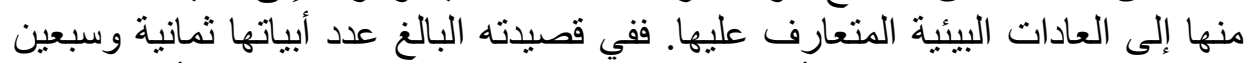

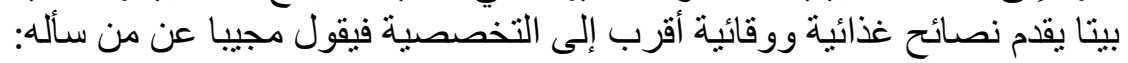

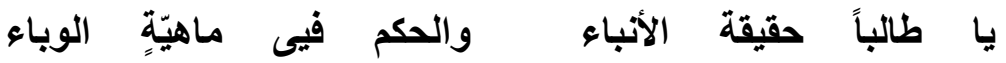

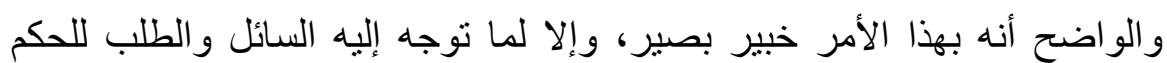

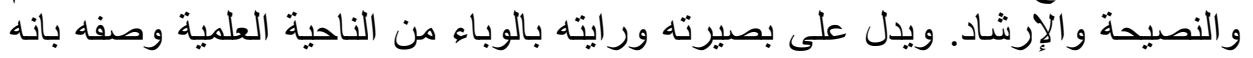

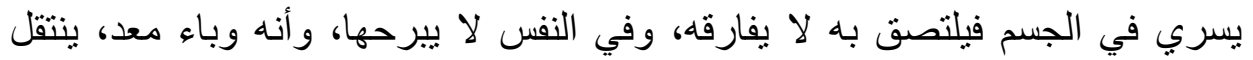
باللمس:

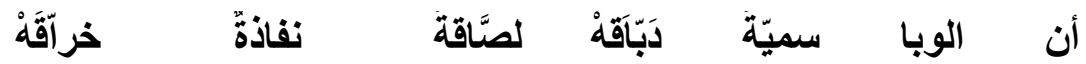
يسيح في الأبدان سيح الدهِ إذا سرى في الصوف أو في القطنِ

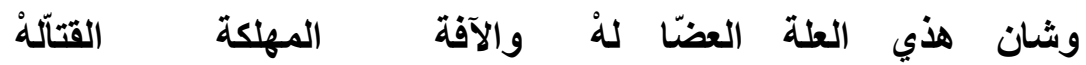

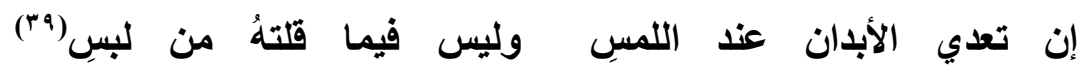
ثم يعرض لبعض الأعراض الناتجة عن الإصابة بهذا الوباء من قتشعريرة و اخضر ار اللون و ألم تحت الإبط، وخلف الأذن، و في الركبنين فيقول:

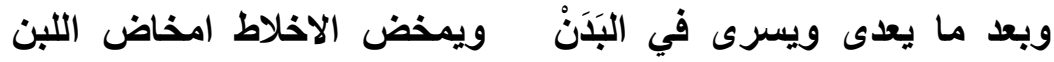
يبان في الجسم إذا ما اقشعز من موضع مسترقث أو أكثرْ والنفذ منهُ رُبَ في الاباط يبدو عقيب المخض والاخباطِ

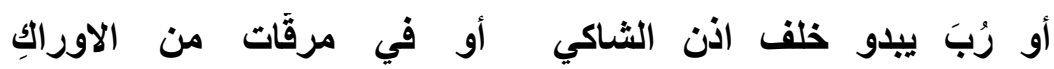

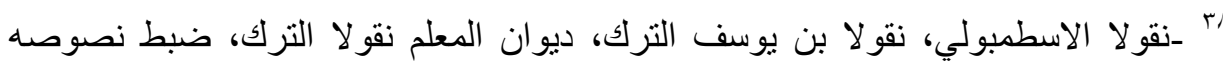

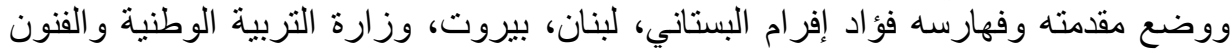

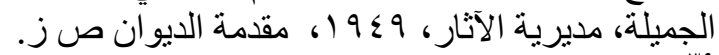
$\wedge \Gamma$ ـ ـ السابق ص ع 


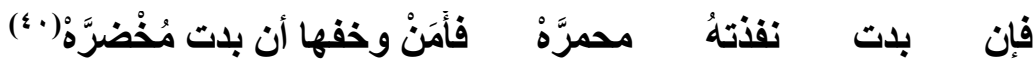
ويذكر نقو لا أن الوباء مرض أعيا الأطباء ومنه كلُّو ا، وأنهم ينصحون بالابتعاد عن الإهن

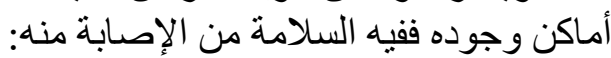

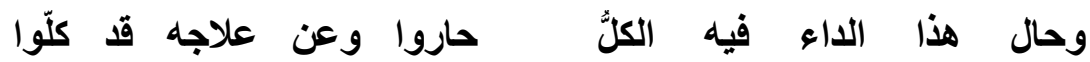

فاستجمعوا الراي به واعتمدوا أن حلَّ يوماً في مكانٍ بعدوا(1؛)

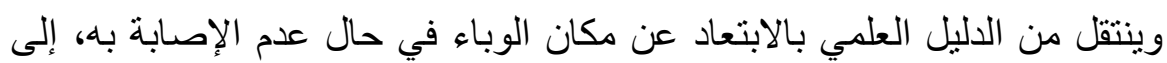

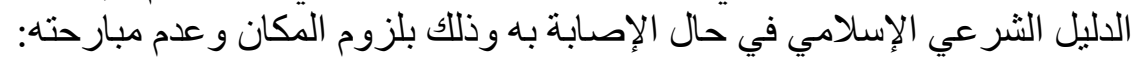

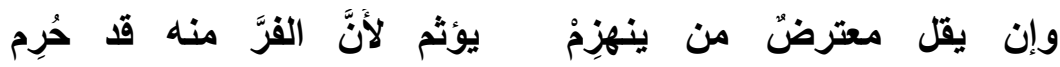

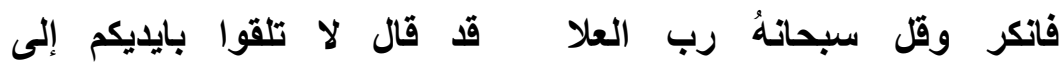
فلا يخفى ما في البيتين من استشهاد بأمر الرسول الكريم صلى الله عليه وسلم بعدم

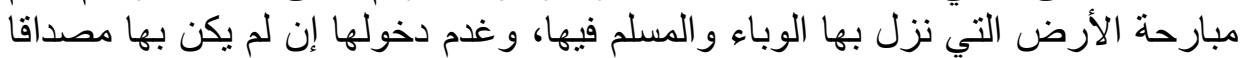

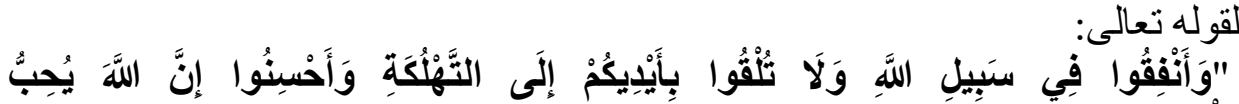

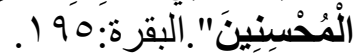

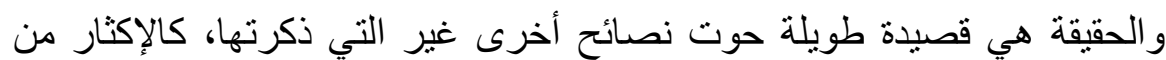

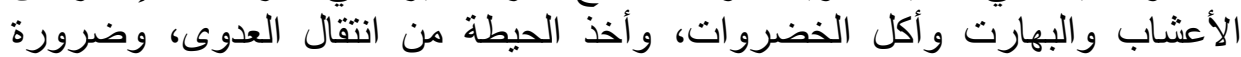

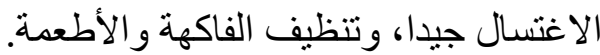

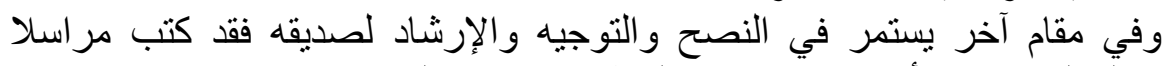

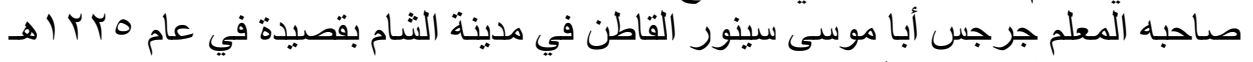

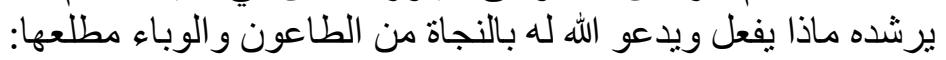

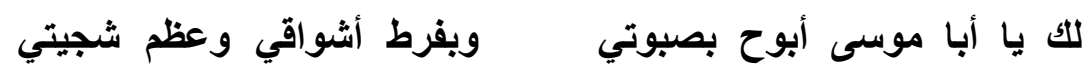

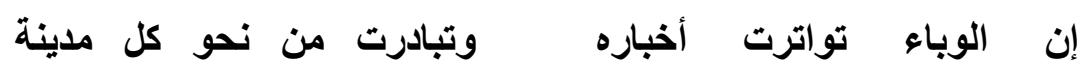


وإذا توكد سوف ندخل للخبا بتوكل منا على ذي العزة(r\&) ومع هذه الاحتياطات هنالك بعض النصائح الغذائية التي لا يجب أن يغفلها صاحبه:

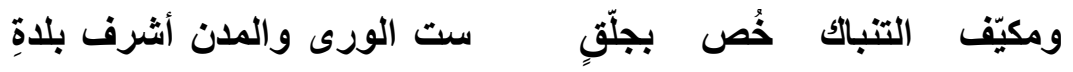
فلذاك جيتك راجياً جدواك في رطلين منه من عظيم القيمةِ

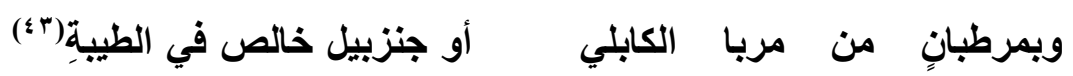

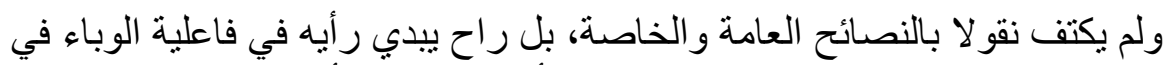

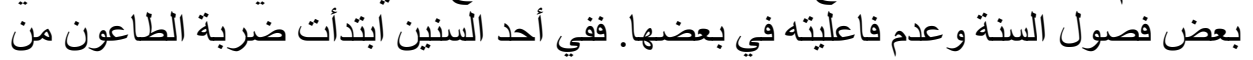

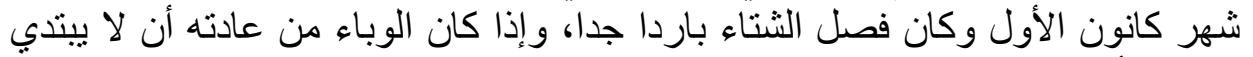

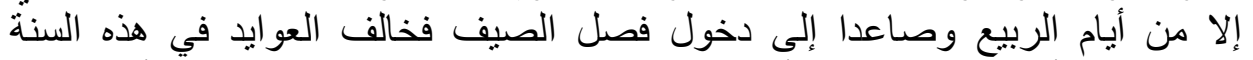

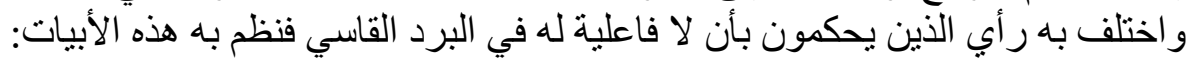

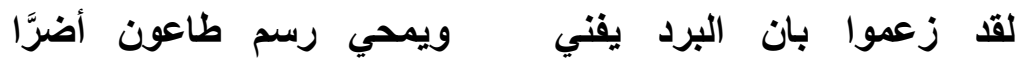

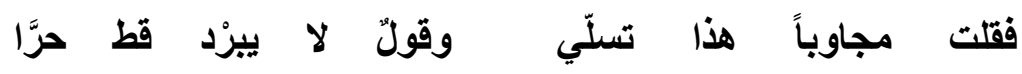

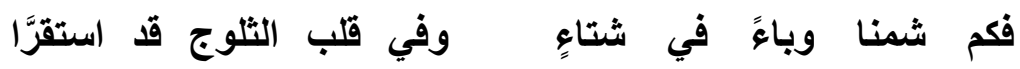

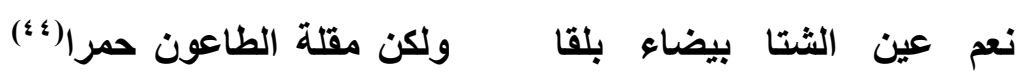
وكما نصح و هنا، فقد رثاو وعزى، فقال في وفاة غنطوس يمين الترك:

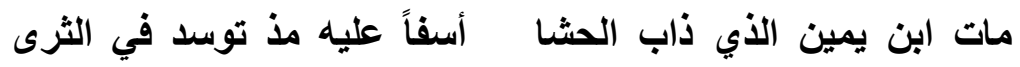
تباً لها سنة الوبا أرخت كم فيها على توما بكيت تحسر|(\&)

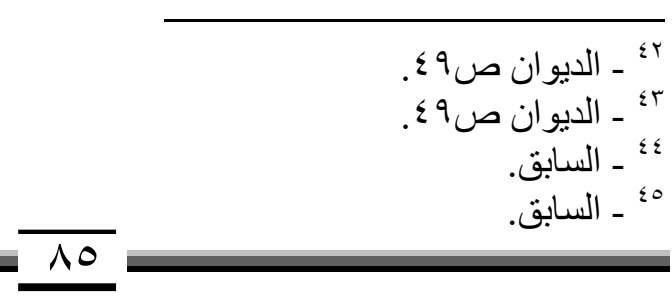


وبعد استعراض ما كتبه الثاعران يمكنتا أخذ عدة ملحوظات، واستكناه لمح وإشار ات:

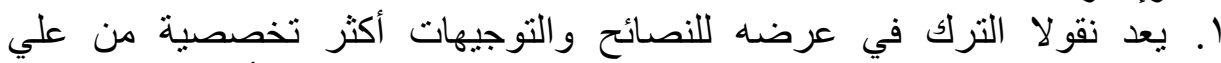

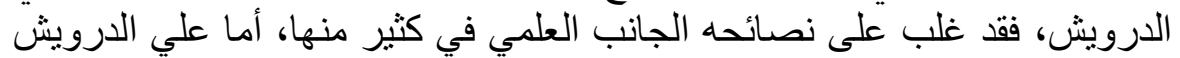

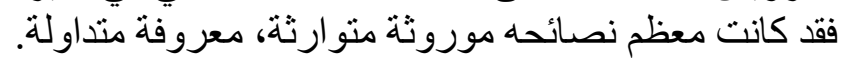

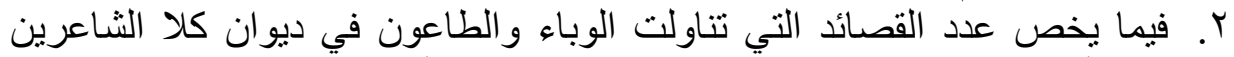

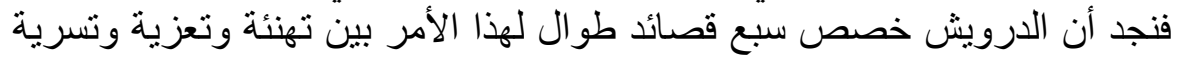

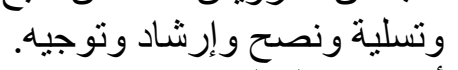

r. أما نقو لا الترك فقد حوى ديو انه عله على كثرته ثلاث قصائد ومقطو عتين تناول فيها ما

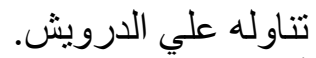

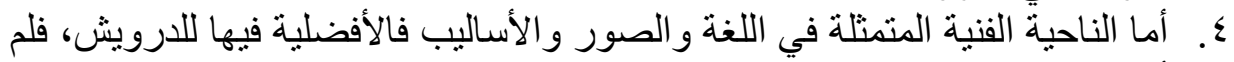

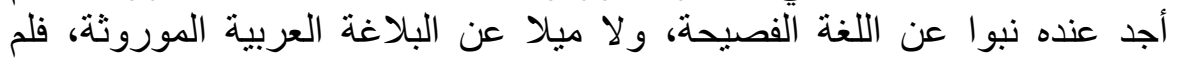

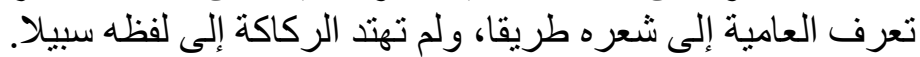

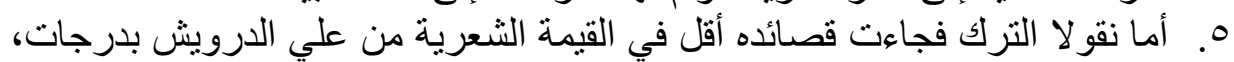

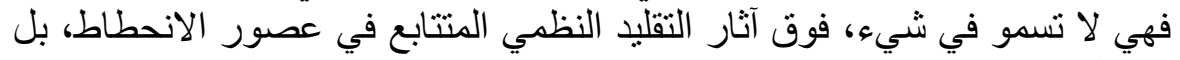

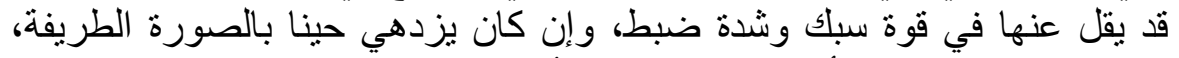

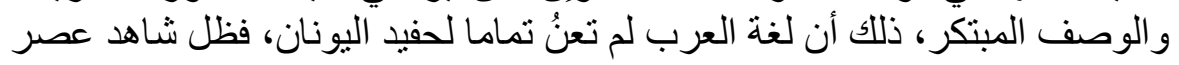

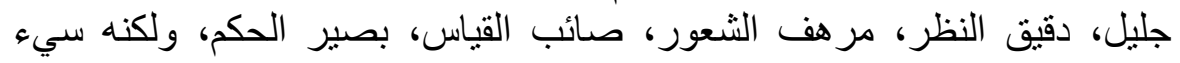
التعبير. 7. كلا الثاعرين مهنم بقضايا عصره، حريص على إبداء الرأي والنصح، تربطه

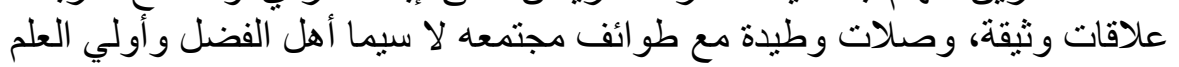
و النهى.

وبعد هذا العرض الموجز عن الوباء في شعر علي الدرويش ونقولا نتائج البحث:

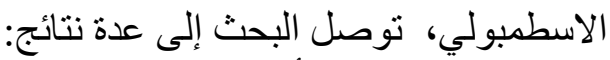

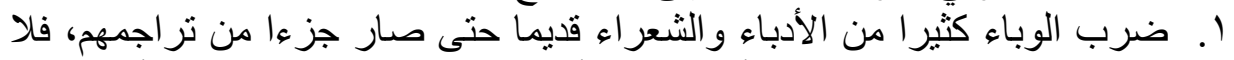

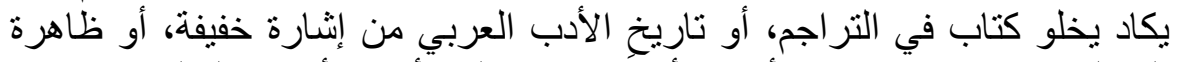

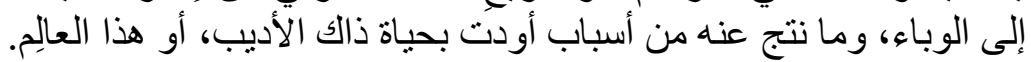

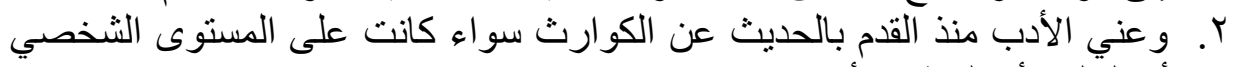
أو القبلي، أو الوطني، أو الإنساني. 


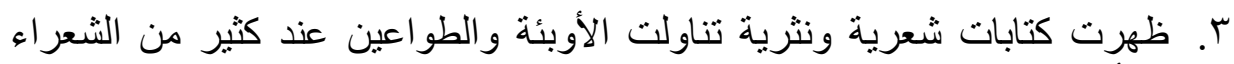

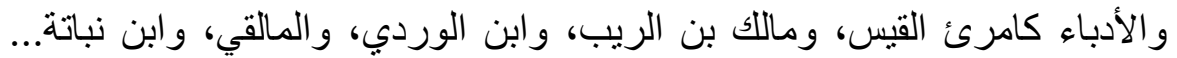

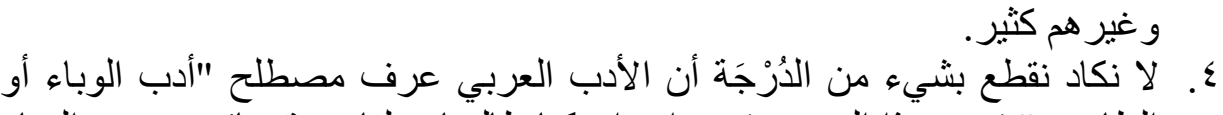

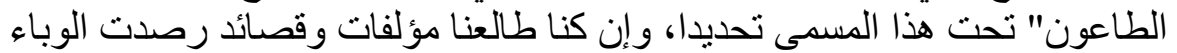

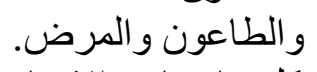

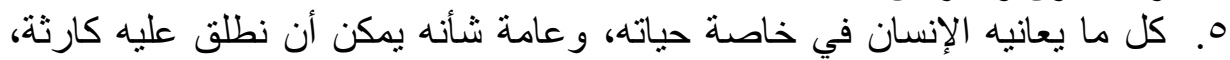

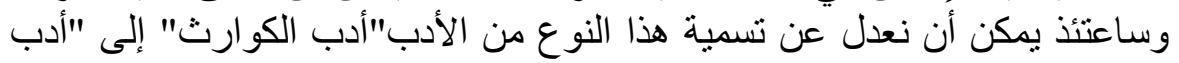

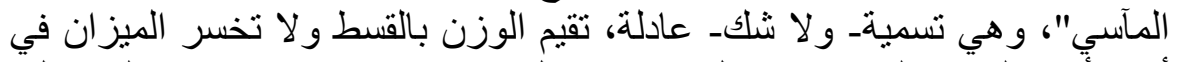

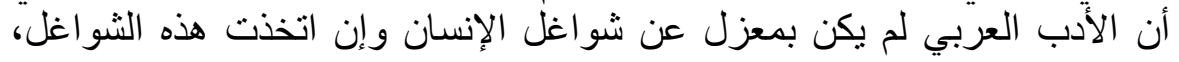
وتللك الدو اهي مسميات حديثة.

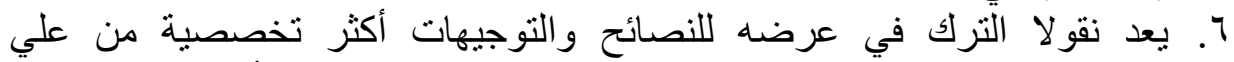

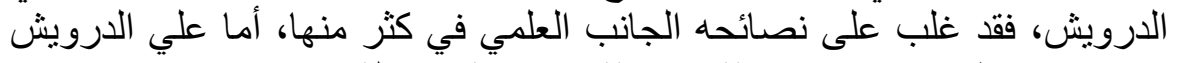

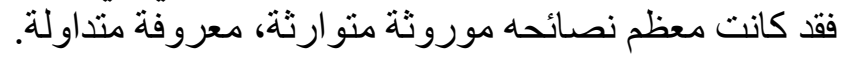

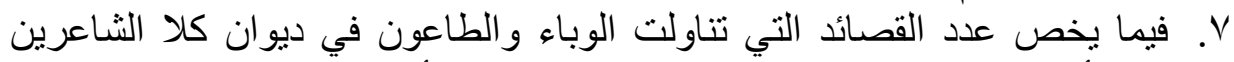

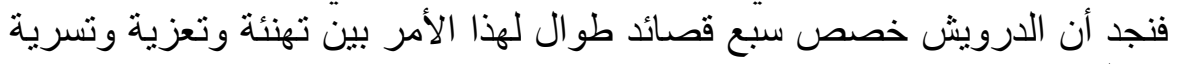

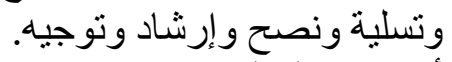

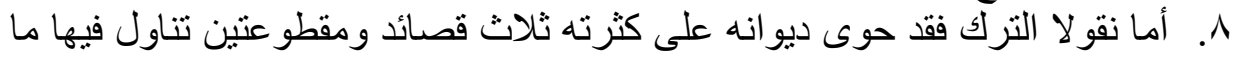
تناوله علي الدرويش.

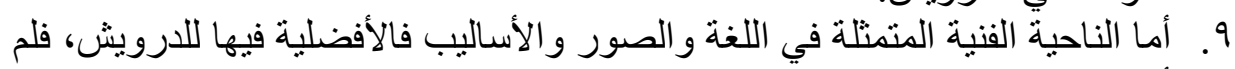

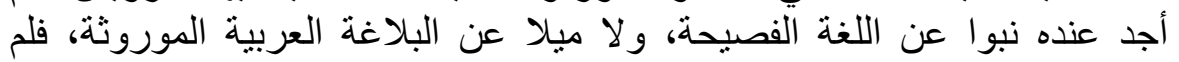

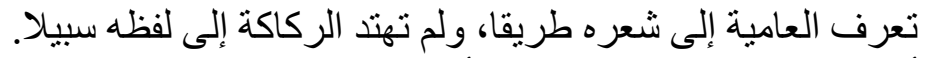

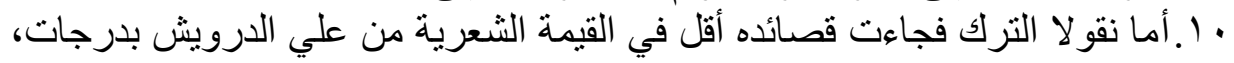

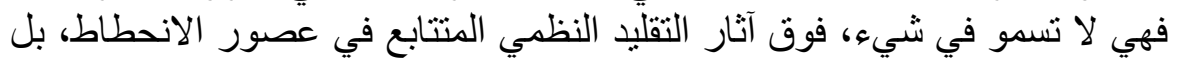

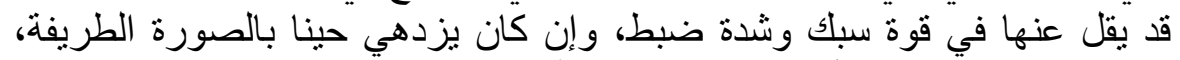

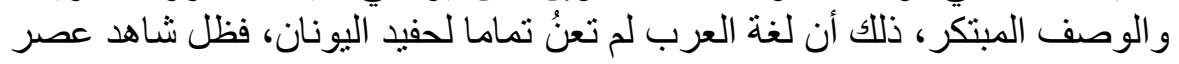
جليل، دقيق النظر، مرهف الثعور، صائب القياس، بصير الحئ الحكم، ولكنه سيء

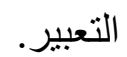
1) كلا الثاعرين مهتم بقضايا عصره، حريص على إبداء الرأي والنصح، تربطه

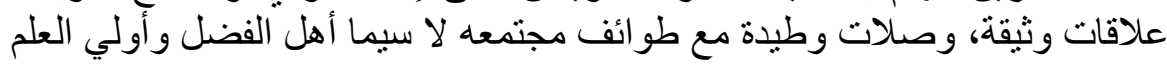
و النهى. 
المصادر والمراجع

القرآن الكريم

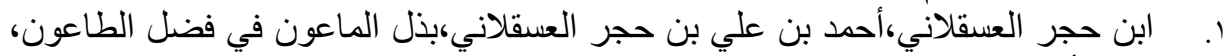

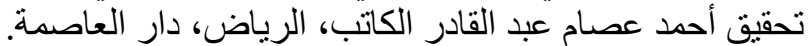

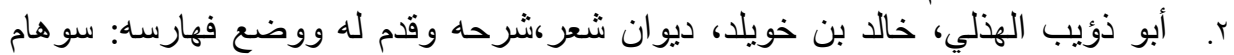

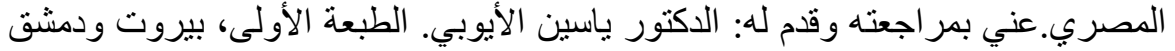

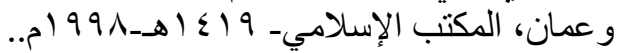

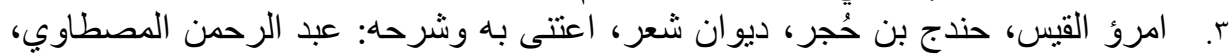

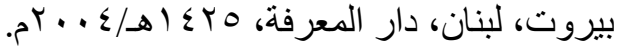

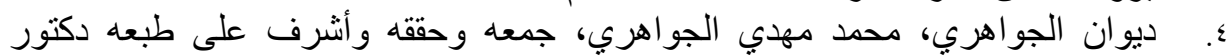

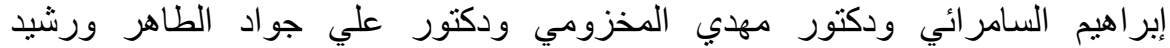

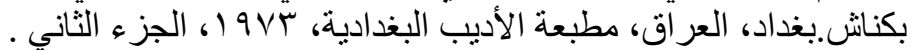

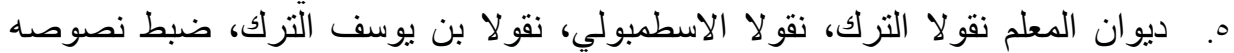

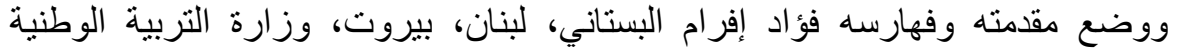

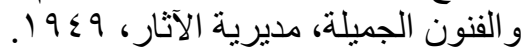

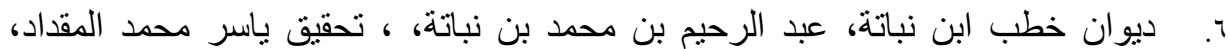

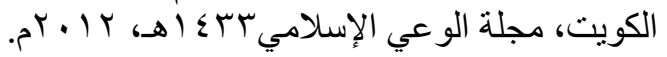

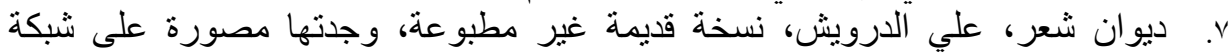

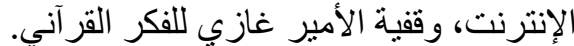

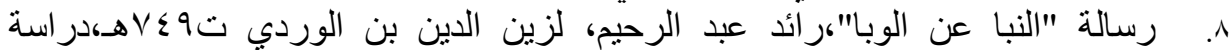

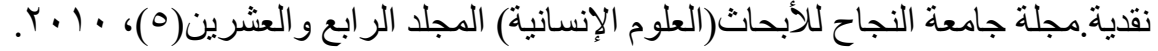

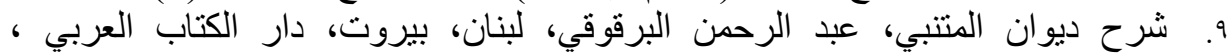

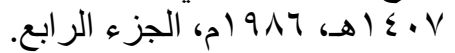

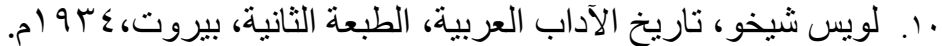

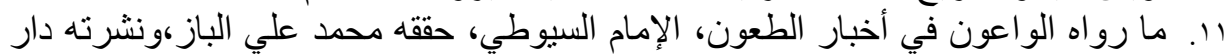

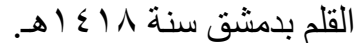

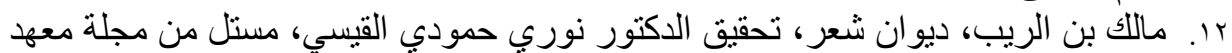

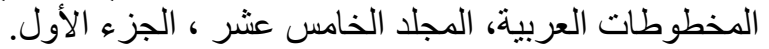

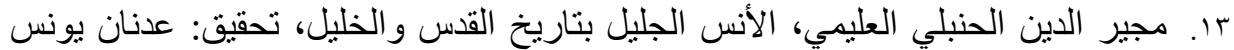

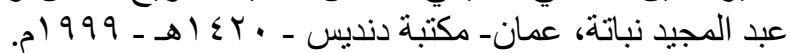

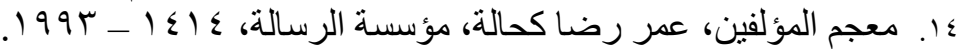

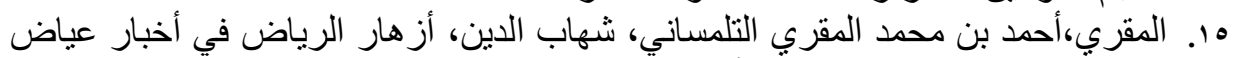

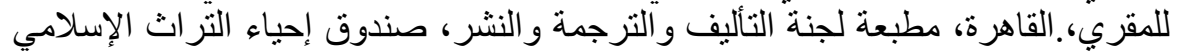
الششترك بين المملكة المغربية ودولة الإمار ات المتحدة. 